\title{
Solar Cell Technology Selection for a PV Leaf Based on Energy and Sustainability Indicators-A Case of a Multilayered Solar Photovoltaic Tree
}

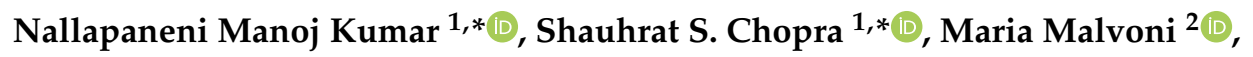 \\ Rajvikram Madurai Elavarasan ${ }^{3}$ (D) and Narottam Das 4,5 (D) \\ 1 School of Energy and Environment, City University of Hong Kong, Kowloon, Hong Kong \\ 2 School of Electrical and Computer Engineering, National Technical University of Athens, \\ 15780 Athens, Greece; maria.malvoni@gmail.com \\ 3 Electrical and Automotive Parts Manufacturing Unit, AA Industries, Chennai 600123, India; \\ rajvikram787@gmail.com \\ 4 School of Engineering and Technology, Central Queensland University Australia, Melbourne, \\ VIC 3000, Australia; n.das@cqu.edu.au \\ 5 Centre for Intelligent Systems, School of Engineering and Technology, Central Queensland University, \\ Brisbane, QLD 4000, Australia \\ * Correspondence: mnallapan2-c@my.cityu.edu.hk (N.M.K.); sschopra@cityu.edu.hk (S.S.C.)
}

Received: 13 October 2020; Accepted: 3 December 2020; Published: 5 December 2020

check for updates

\begin{abstract}
Harnessing energy from the sunlight using solar photovoltaic trees (SPVTs) has become popular at present as they reduce land footprint and offer numerous complimentary services that offset infrastructure. The SPVT's complimentary services are noticeable in many ways, e.g., electric vehicle charging stations, landscaping, passenger shelters, onsite energy generated security poles, etc. Although the SPVT offers numerous benefits and services, its deployment is relatively slower due to the challenges it suffers. The most difficult challenges include the structure design, the photovoltaic (PV) cell technology selection for a leaf, and uncertainty in performance due to weather parameter variations. This paper aims to provide the most practical solution supported by the performance prioritization approach (PPA) framework for a typical multilayered SPVT. The proposed PPA framework considers the energy and sustainability indicators and helps in reporting the performance of a multilayered SPVT, with the aim of selecting an efficient PV leaf design. A three-layered SPVT (3-L SPVT) is simulated; moreover, the degradation-influenced lifetime energy performance and carbon dioxide $\left(\mathrm{CO}_{2}\right)$ emissions were evaluated for three different PV-cell technologies, namely crystalline silicon (c-Si), copper indium gallium selenide (CIGS), and cadmium telluride (CdTe). While evaluating the performance of the 3-L SPVT, the power conversion efficiency, thermal regulation, degradation rate, and lifecycle carbon emissions were considered. The results of the 3-L SPVT were analyzed thoroughly, and it was found that in the early years, the c-Si PV leaves give better energy yields. However, when degradation and other influencing weather parameters were considered over its lifetime, the SPVT with c-Si leaves showed a lowered energy yield. Overall, the lifetime energy and $\mathrm{CO}_{2}$ emission results indicate that the CdTe PV leaf outperforms due to its lower degradation rate compared to c-Si and CIGS. On the other side, the benefits associated with CdTe cells, such as flexible and ultrathin glass structure as well as low-cost manufacturing, make them the best acceptable PV leaf for SPVT design. Through this investigation, we present the selection of suitable solar cell technology for a PV leaf.
\end{abstract}

Keywords: solar energy materials; crystalline solar cells; thin films solar cells; applications of solar cells; photovoltaic leaf; solar tree; degradation rate; solar tree performance; optimal mounting of PV leaf 


\section{Introduction}

Photovoltaic (PV) systems allow consumers to generate useful electricity sustainably from incident sunlight using the PV devices at the load centers themselves. In addition, PV also offers numerous other benefits that typically fall under Sustainable Development Goal 7 (SDG7) of the United Nations Development Programme (UNDP), i.e., "ensuring affordable, reliable, sustainable, and modern energy for all" [1]. These benefits within the context of SDG7 were validated in [2]. Overall, in the modern power sector, $\mathrm{PV}$ use has gained much popularity; currently, it is one of the pioneers in renewable power generation. Day by day, PV and its associated technologies are becoming more mature. Coming to PV alone, the seen advances mainly lie in installation, mounting configuration, portable PV device design, on-board energy generation, and many small, medium, and large-scale energy consuming centers [3].

Traditionally, we could see mostly open-mount photovoltaics (OMPV) and roof-mount photovoltaics (RMPV) power plants, and these are typically classified under two groups: off-grid and on-grid [4]. The OMPV and RMPV plants are otherwise called an open rack, and rooftop or roof attached [4]. At present, we could see different types of PV technology-based power generation plants, and they are visually represented in Figure 1.

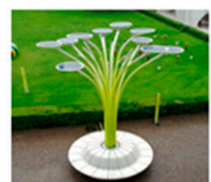

SPVT

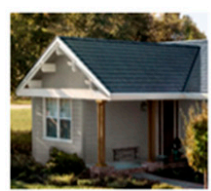

RIPV

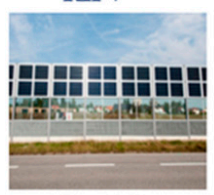

RoAPV

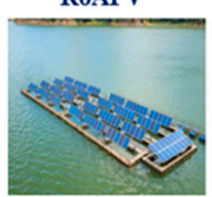

FSPV

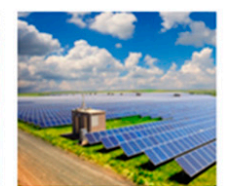

OMPV

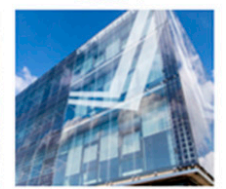

FIPV

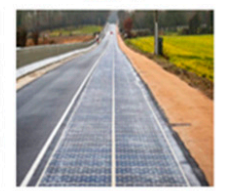

RoIPV

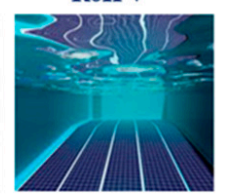

SPV

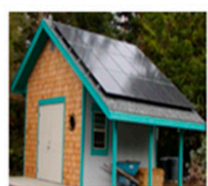

RMPV

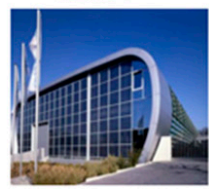

BIPV

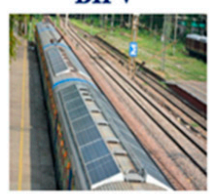

LoMPV

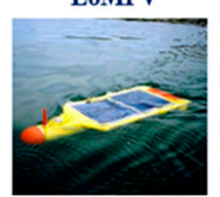

UobSPV

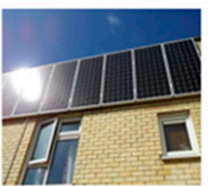

BAPV

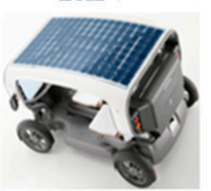

VAPV

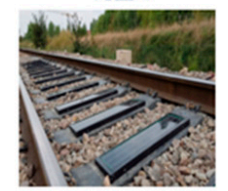

RaTIPV

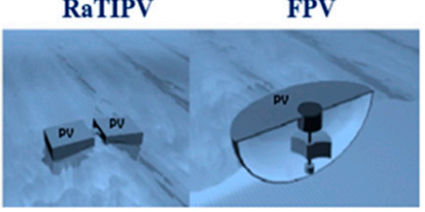

Wavevoltaics or Wavoltaics

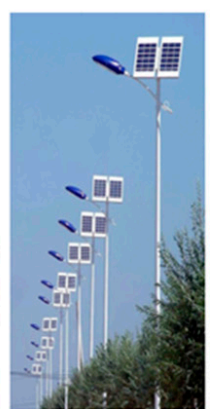

PMPV

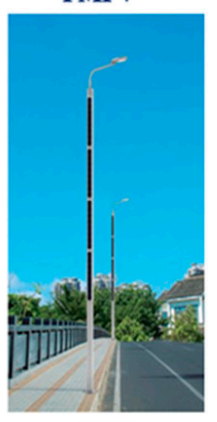

PIPV

Figure 1. Visual representation of different types of solar photovoltaic plants based on the installation and mounting area. SPVT = solar photovoltaic tree; OMPV = open-mount photovoltaics; RMPV = roof-mount photovoltaics; $\mathrm{BAPV}=$ building attached photovoltaics; $\mathrm{CMSPV}=$ canopy-mounted solar photovoltaics; RIPV = roof-integrated photovoltaics; FIPV = façade-integrated photovoltaics; BIPV = building-integrated photovoltaics; VAPV = vehicle attached photovoltaics; VIPV = vehicle-integrated photovoltaics; RoAPV = road-attached photovoltaics; RoIPV = road-integrated photovoltaics; LoMPV = locomotive-mount photovoltaics; RaTIPV $=$ rail track integrated photovoltaics; FPV = floating photovoltaics or floatovoltaics; FSPV = floating solar photovoltaics; SPV = submerged photovoltaics; UobSPV = underwater on-board solar photovoltaics; PMPV = pole mounted-photovoltaics; PIPV = pole-integrated photovoltaics. 
The recent advances in PV installations include roof-integrated photovoltaics (RIPV) [5], façade-integrated photovoltaics (FIPV) [6], building-integrated photovoltaics (BIPV) [7,8], building attached photovoltaics (BAPV) [8], canopy-mount solar photovoltaics (CMSPV) [9], vehicle-integrated photovoltaics (VIPV) [10]; road- and rail-integrated photovoltaics (RRIPV) [11,12], pole-mounted photovoltaics (PMPV) [13], floating solar photovoltaics (FSPV) or floatovoltaics (FPV) [14], underwater on-board solar photovoltaics (UobSPV) or submerged photovoltaics (SPV) [15], wavevoltaics [16], and solar photovoltaic tree (SPVT) [17].

The above-listed PV plants are briefly described in Table 1, which also presents considerations of the preferred solar cell technologies, the medium of installation (e.g., land, water, and X-integrated), and land footprints. Here, $\mathrm{X}$-integrated refers to integrating solar PV cells onto the peripherals of the buildings, façades, canopies, vehicles, road, rail tracks, poles, etc. Among all the discussed PV plant types in Table 1, only a few are commercialized and used for power generation, and few others are still in the research stage. OMPV and SPVTs are installed on the land surface, and they are accountable for the land footprint $[3,4,18,19]$. Apart from these two, few other PV plants are generally installed on the water bodies (e.g., FPV, SPV, UobSPV, etc.) and peripherals of different infrastructures (e.g., BIPV, PMPV, etc.) such as buildings, poles, roads, and rail tracks [5-23]. Most of these do not cause any direct land footprint; however, a few of them have an apparent indirect land footprint, which is acceptable as they provide other benefits based on the inherent nature of the infrastructure (e.g., buildings are necessary for shelter; poles are required for electrical and communication cabling; street lighting, roads, and rail tracks allow for transportation). Upon comparing the land footprint of all the listed PV plant types, the SPVT requires a very minimum land surface (which is negligible compared to others) and offers many complimentary services $[17,18]$. The provided services are noticeable in many ways, e.g., electric vehicle charging stations, landscaping, passenger shelters, onsite energy generation for powering the public lighting, and these have a variety of usages, such as equipping surveillance cameras, etc. Overall, it is understood that the offered services by SPVTs help to offset infrastructure and its material needs. Even though a SPVT provides many benefits, its deployment in the modern energy sector is relatively slower due to the challenges it suffers. To understand the challenges faced by SPVTs, a literature review is carried out in this paper.

The current research on SPVTs focuses on the design aspects, energy performance, and influence of weather parameters on the performance. The design of a SPVT is mostly bio-inspired, and the SPVT is primarily used as an attraction in urban landscaping. Hence, the design is made more of a decorative tree where the solar PV cells are arranged as leaves to an edifice. This has resulted in layered structures, depending on the possibility and applicability of the number of layers [17-19]. Hyder et al. (2018) presented a study comparing the different layer designs of SPVTs, and they observed that as the layers increase, the output power generated by the SPVT increases [19]. This is because of the installed PV leaves on the edifice. Considering these layered structures, at present, SPVTs are available in many designs. These designs include a spiraling phyllotaxy, a Fibonacci pattern, a single trunk with branches, a 3-axis symmetric design, panels on a natural tree, a solar palm tree, and a hemispherical semi-dome design [24-29]. After the layer structure and design, the PV leaf arrangement in the SPVT is essential, and in almost every SPVT, the PV leaf arrangement also varies. In [19], six SPVT designs were simulated, and the results show that SPVT designs, on average, produce $41 \%$ higher energy yields than the conventional PV system. In [28], an SPVT in a solar palm tree design with 12 leaf-shape organic PV cells was assembled; the outdoor performance in dual-mode operation is demonstrated, and the results show that SPVTs are feasible. Overall, the literature states that SPVTs are better in terms of energy efficiency $[18,19,24-28]$. 
Table 1. Comparing different types of solar photovoltaic plant types based on the installation considering recent advances

\begin{tabular}{|c|c|c|c|c|c|}
\hline Photovoltaic Plant Type & Installation Medium & Brief Description & $\begin{array}{l}\text { Most Preferred Solar } \\
\text { Cell Technology }\end{array}$ & Land Footprint & Reference \\
\hline Solar photovoltaic tree & $\begin{array}{l}\text { Land surface and the } \\
\text { existing poles or towers }\end{array}$ & $\begin{array}{l}\text { Photovoltaics modules are mounted as leaves on tree-like } \\
\text { structures }\end{array}$ & $\begin{array}{l}\text { Crystalline silicon and } \\
\text { thin-film solar cells }\end{array}$ & $\begin{array}{l}\text { Very minimum land } \\
\text { footprint }\end{array}$ & {$[18,19]$} \\
\hline Open mount & Land surface & $\begin{array}{l}\text { Photovoltaics modules are installed on iron mounting } \\
\text { structures that are laid on the ground surface with } \\
\text { concrete support }\end{array}$ & \multirow[t]{3}{*}{$\begin{array}{l}\text { Mono and polycrystalline } \\
\text { silicon }\end{array}$} & $\begin{array}{l}\text { Very high land footprint } \\
\text { and depends on the plant } \\
\text { capacity }\end{array}$ & [3] \\
\hline Roof mount & \multirow{6}{*}{$\begin{array}{l}\text { Building outer } \\
\text { peripherals }\end{array}$} & \multirow{3}{*}{$\begin{array}{l}\text { In roof-mount, building-attached, and canopy-mount } \\
\text { solar PV, the photovoltaic modules are attached to the } \\
\text { building's outer peripherals using a rail-less or railed } \\
\text { support structure (e.g., windows, roofs, façades, etc.) }\end{array}$} & & \multirow{13}{*}{$\begin{array}{l}\text { No direct land footprint } \\
\text { but there exists indirect } \\
\text { land footprint }\end{array}$} & {$[3,4]$} \\
\hline Building attached & & & & & [8] \\
\hline Canopy-mount solar & & & \multirow{5}{*}{$\begin{array}{l}\text { Crystalline silicon, } \\
\text { amorphous silicon, thin } \\
\text { films like CdTe, CIGS, and } \\
\text { flexible solar cells }\end{array}$} & & [9] \\
\hline Roof integrated & & $\begin{array}{l}\text { In roof-integrated, façade-integrated, and } \\
\text { building-integrated PV, the photovoltaic modules are } \\
\text { integrated into the outer building peripherals by }\end{array}$ & & & [5] \\
\hline Façade integrated & & replacing the building structures, such as windows, roofs, & & & [6] \\
\hline Building integrated & & & & & [20] \\
\hline $\begin{array}{l}\text { Vehicle integrated or } \\
\text { vehicle mount }\end{array}$ & $\begin{array}{l}\text { Vehicle outer } \\
\text { peripherals }\end{array}$ & $\begin{array}{l}\text { Photovoltaics modules are installed or integrated into } \\
\text { vehicle structures such as window glass, sunroof, etc. }\end{array}$ & & & [10] \\
\hline Road and rail integrated & $\begin{array}{l}\text { On-road and rail track } \\
\text { infrastructure }\end{array}$ & $\begin{array}{l}\text { Photovoltaics modules are integrated into the road, rail } \\
\text { tracks, and other infrastructure }\end{array}$ & \multirow{2}{*}{$\begin{array}{l}\text { Crystalline silicon, } \\
\text { amorphous silicon, } \\
\text { thin-film, and flexible } \\
\text { solar cells }\end{array}$} & & [11] \\
\hline $\begin{array}{l}\text { Pole mounted and } \\
\text { integrated }\end{array}$ & $\begin{array}{l}\text { Outer peripherals of the } \\
\text { street poles }\end{array}$ & $\begin{array}{l}\text { Photovoltaics modules are attached or integrated to the } \\
\text { poles, e.g., streetlights }\end{array}$ & & & [12] \\
\hline $\begin{array}{l}\text { Floating solar or } \\
\text { Floatovoltaics }\end{array}$ & $\begin{array}{l}\text { Surface of the water } \\
\text { body }\end{array}$ & $\begin{array}{l}\text { Photovoltaics modules are mounted onto the floating } \\
\text { structures. }\end{array}$ & Dual glass solar cells & & [21] \\
\hline $\begin{array}{l}\text { Underwater on-board } \\
\text { solar }\end{array}$ & \multirow[t]{2}{*}{$\begin{array}{l}\text { Underwater at varying } \\
\text { depths of water }\end{array}$} & \multirow[t]{2}{*}{$\begin{array}{l}\text { Photovoltaics modules are mounted or integrated onto the } \\
\text { robot structures or underwater infrastructure peripherals }\end{array}$} & \multirow{2}{*}{$\begin{array}{l}\text { Crystalline silicon, } \\
\text { thin-film, and flexible } \\
\text { solar cells }\end{array}$} & & [22] \\
\hline Submerged & & & & & [14] \\
\hline Wavevoltaics & $\begin{array}{l}\text { Surface of the wave } \\
\text { energy device or any } \\
\text { floating buoy }\end{array}$ & $\begin{array}{l}\text { Photovoltaics modules are mounted onto the wave energy } \\
\text { devices like a buoy }\end{array}$ & $\begin{array}{l}\text { Thin-film and other } \\
\text { flexible solar cells }\end{array}$ & & [23] \\
\hline
\end{tabular}


However, most literature claims have not considered the critical factors that affect PV cell performance in the long run, such as orientation and tilt, the difference in height for each layer in SPVT design, wind and temperature effects, degradation rate, and cell technology. In this article, a brief study is presented to act as the best approach in selecting the best performing PV leaf for an SPVT design by considering the above-said vital factors.

Overall, it is clear that the most difficult challenges with SPVTs lie with the structure design, the solar cell technology selection for a leaf, and energy performance. Moreover, academics, researchers, and the industry workforce are working together to address these challenges to facilitate the deployment of SPVTs into sectors such as energy, built environments, and others wherever it is applicable. Therefore, this paper aims to provide the most practical solution for a typical multilayered SPVT, and the following objectives are undertaken in this study:

- A framework with a performance prioritization approach (PPA) is proposed to report the performance of a multilayered SPVT intending to select an efficient PV leaf design.

- A three-layered SPVT (3-L SPVT) that has nine leaves-where the upper layer has only one solar PV leaf, the middle and bottom layers have four solar PV leaves each-is simulated, and lifetime energy performance is evaluated for three different PV cell technologies, namely crystalline silicon (c-Si), copper indium gallium selenide (CIGS), and cadmium telluride (CdTe). While evaluating the 3-L SPVT's performance, power conversion efficiency, thermal regulation, and degradation rate are considered.

- An analysis of the investigated results is carried out, and at the same time the best performing solar PV leaf for a three-layered SPVT is identified among the c-Si, CIGS, and CdTe PV technologies.

This paper is structured into six sections. In Section 2, a brief description of the proposed 3-L SPVT is given. Section 3 provides the performance modeling. Section 4 describes the proposed framework, i.e., the performance prioritization approach. Performance results of the 3-L SPVT with different solar cell type PV leaves and the related discussion are provided in Section 5. The conclusions are drawn and presented in Section 6.

\section{Description of the Proposed Three-Layered Solar Photovoltaic Tree}

This section provides a brief description of the design of the proposed SPVT. The layered structure of the SPVT was modelled with a provision for mounting different solar cells as PV leaves at fixed tilt angles and was designed using SolidWorks (which is a computer-aided design and computer-aided engineering computer program) modeling.

In the SPVT, the primary components include an edifice (generally called a central tower whose shapes can be varied, but in this study it is of a circular pole), branches, PV leaf holders for each branch, and the PV leaves. In the proposed SPVT, a total of 9 branches are considered and arranged in 3 layers.

The principal purpose of using a layered structure is to capture the incoming sunlight from the sun in various directions. The PV modules are well suited for converting the received beam of solar radiation from all directions into useful energy in such designs. Further, by having adjustments in the PV-leaf tilt and azimuthal angles, the energy outputs can be optimized. Overall, the PV leaves in the layered structure allows the SPVT to follow the respective installed site's sun path. Hence, at first, all the components of the SPVT are designed separately and later assembled to form the SPVT using the assembly function in SolidWorks. In Figure 2, the details about the SPVT are shown. The designed 3-L SPVT is shown in Figure 2a. It can be seen that the SPVT structure contains a long edifice, which is generally referred to as the trunk for SPVT. The trunk is arranged with 3 layers, where the bottom $(5 \mathrm{~m}$ above the ground) and the middle layer ( $7 \mathrm{~m}$ above the ground) have 4 strips commonly known as branches, each branch elevating to one of the eight directions (i.e., north, northeast, east, southeast, south, southwest, west, northwest). The upper layer (9 $\mathrm{m}$ above the ground) has only one branch facing the open sky. Overall, the designed 3-L SPVT has 9 branches, and each branch holds a PV leaf at a fixed tilt angle as depicted in Table 2. 
a)

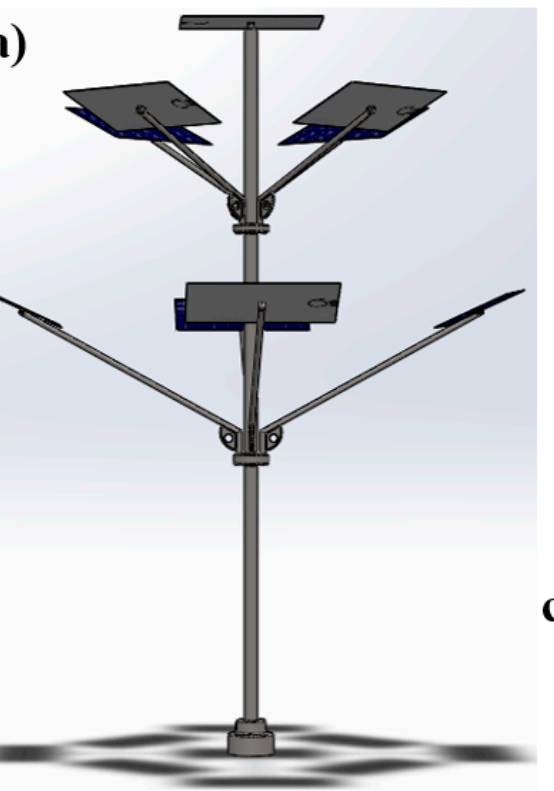

b)

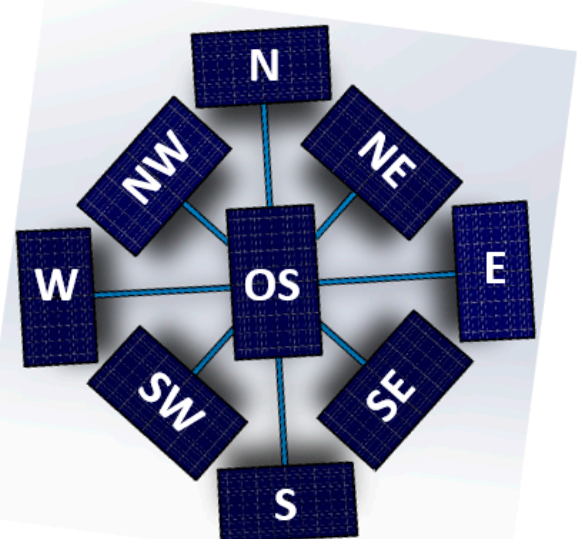

c)

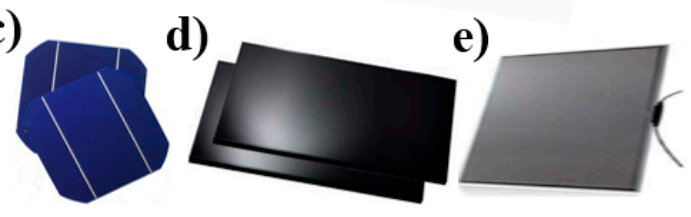

Figure 2. The schematic structure of the solar photovoltaics tree (SPVT): (a) Three-layered SPVT;

(b) SPVT showing the PV leaf arrangement; (c) c-Si PV cells; (d) CIGS PV cells; (e) CdTe PV cells.

The arrangement of the PV leaf on each branch of the SPVT, along with its direction, is shown in Figure $2 \mathrm{~b}$. A PV leaf is arranged on each branch of the SPVT, as the physical constraints related to shadowing were also considered. Here, the PV branches are placed to avoid such shadowing, and hence in each layer, a $2 \mathrm{~m}$ height difference is considered; the PV leaves are mounted in different orientations, having exactly a $45^{\circ}$ angle apart in a way that no panel is oriented to same direction, irrespective of the layer. Finally, these branches are exposed to the sunlight and ultimately generate electricity.

Table 2. Installation configuration of photovoltaic leaves in the three-layered solar photovoltaic tree.

\begin{tabular}{|c|c|c|c|c|c|}
\hline Solar Tree & PV Leaf Layer & $\begin{array}{l}\text { Number of PV } \\
\text { Leaves in a Layer }\end{array}$ & PV Leaf & Orientation & Tilt Angle $\left({ }^{\circ}\right)$ \\
\hline \multirow{9}{*}{$\begin{array}{l}\text { Three-layer } \\
\text { design }\end{array}$} & Upper layer & 1 & $\mathrm{PV}_{u l-\mathrm{OS}}$ & Open sky & 0 \\
\hline & \multirow{4}{*}{ Middle layer } & \multirow{4}{*}{4} & $\mathrm{PV}_{m l-N E}$ & Northeast & \multirow{4}{*}{25.4358} \\
\hline & & & $\mathrm{PV}_{m l-S E}$ & Southeast & \\
\hline & & & $\mathrm{PV}_{m l-S W}$ & Southwest & \\
\hline & & & $\mathrm{PV}_{m l-N W}$ & Northwest & \\
\hline & \multirow{4}{*}{ Bottom layer } & \multirow{4}{*}{4} & $P V_{b l-N}$ & North & \multirow{4}{*}{25.4358} \\
\hline & & & $P V_{b l-E}$ & East & \\
\hline & & & $\mathrm{PV}_{b l-S}$ & South & \\
\hline & & & $\mathrm{PV}_{b l-W}$ & West & \\
\hline
\end{tabular}

Note: $\mathrm{PV}=$ photovoltaics; $\mathrm{ul}=$ upper layer; $\mathrm{ml}=$ middle layer; $\mathrm{bl}=$ bottom layer ${ }^{\circ}=$ degree sign; $\mathrm{OS}=$ open $\mathrm{sky}$; $\mathrm{NE}=$ northeast; $\mathrm{SE}=$ southeast; $\mathrm{SW}=$ southwest; $\mathrm{NW}=$ northwest; $\mathrm{N}=$ north; $\mathrm{E}=$ east; $\mathrm{S}=$ south; $\mathrm{W}=$ west.

However, the generated electricity potentials would vary upon the chosen solar cell technology; in addition, the exposed weather conditions would have an impact on the overall performance. To understand the variation in electricity potentials for the chosen solar cell technologies used as the PV leaf for the SPVT, this study investigates the energy performance and lifecycle-based emissions. The solar cell technologies considered for the PV leaf are shown in Figure $2 c-e$, and these include the crystalline silicon (c-Si), copper indium gallium selenide (CIGS), and cadmium telluride (CdTe). 
The installation configuration of the PV leaves in each layer and the number of PV leaves used in each layer, along with the mounted tilt angle, is shown in Table 2. Here, the chosen tilt angle is as per the studied location.

\section{Solar Photovoltaic Tree Performance Modelling}

In this section, the proposed SPVT performance modeling based on the energy and sustainability indicators is discussed. The detailed modeling of the weather-parameter-influenced energy outputs and the lifecycle-based emissions for the three solar cell technologies used in the 3-L SPVT are presented in Sections 3.1 and 3.2, respectively.

\subsection{Modeling of the Solar Photovoltaics Tree Energy Output}

The energy output of an SPVT usually depends on the numerous components used in the energy conversion process. For example, the use of the inverter device, i.e., direct current-alternating current (DC-AC), will enable us to harness AC energy outputs from the SPVT. However, the PV modules are primarily designed to produce DC energy outputs. Hence, in the proposed 3-L SPVT, only DC energy outputs were considered for the performance. When modeling the energy output of an entire SPVT, we first modeled the energy outputs for each PV leaf individually. The energy output of a single PV leaf in the proposed 3-L SPVT design is evaluated using Equation (1) [30].

$$
E_{P V \text { Leaf }}={ }_{r e f} \times\left[1-K_{T}\left(T_{P V \text { Leaf }}-T_{r e f}\right)\right] \times A_{P V \text { Leaf }} \times G_{P O-P V \text { Leaf }}
$$

where $E_{P V}$ Leaf is the energy output of a single PV leaf in $\mathrm{kWh}$; ref is the reference efficiency of the chosen solar cell technology for a PV leaf in percentage; $K_{T}$ is the temperature coefficient in percentage $/{ }^{\circ} \mathrm{C}$; $T_{P V \text { Leaf }}$ is the cell temperature of the PV leaf in ${ }^{\circ} \mathrm{C} ; T_{r e f}$ is the reference temperature in ${ }^{\circ} \mathrm{C} ; A_{P V}$ Leaf is the area of the PV leaf in $\mathrm{m}^{2}$; and the $G_{P O-P V \text { Leaf }}$ is the plane of $\mathrm{PV}$ leaf irradiance in $\mathrm{kWh} / \mathrm{m}^{2} /$ day.

As per Equation (1), we need numerous data inputs to model the energy output of a PV leaf. Solar cell efficiency, temperature coefficient, and the area of the PV leaf are the essential data inputs, and they can be obtained from the manufacturer datasheets, as shown in Table 3.

Table 3. Power performance modeling specification of the chosen solar cell technologies as a photovoltaic leaf for the solar photovoltaic tree [31-33].

\begin{tabular}{lccc}
\hline \multicolumn{1}{c}{ Solar Cell Technology } & Efficiency $(\mathbf{\%})$ & Area $\left(\mathbf{m}^{\mathbf{2}}\right)$ & Temperature Coefficient $\left(\mathbf{\%} /{ }^{\mathbf{C}} \mathbf{C}\right)$ \\
\hline Crystalline silicon (c-Si) & 14.90 & & -0.47 \\
Copper indium gallium selenide (CIGS) & 12.10 & 0.72 & -0.45 \\
Cadmium telluride (CdTe) & 14.60 & & -0.34 \\
\hline
\end{tabular}

However, the data related to weather parameters such as the plane of PV leaf irradiance, reference temperatures, and wind speeds need to be obtained from the meteorological stations. Here, the required weather data were obtained from the Indian Meteorological Department (IMD) [34]. The humid subtropical climate is most common to many of the cities in India, and this type of climate is designated as Cwa in the Köppen climate classification. The chosen location experiences relatively hot weather in summer conditions, and throughout the year, the temperature is maintained on an average of 29-30 ${ }^{\circ} \mathrm{C}$. Allahabad (latitude: $25.4299^{\circ} \mathrm{N}$ and longitude: $81.7712^{\circ} \mathrm{E}$ ) is the specific location for which we have collected the solar irradiation data, and the data are the averaged values of a one-year period (2015-2016). However, as per the objective, the proposed PV energy output model accounts for the thermal regulations, and for this, one needs to consider the PV leaf cell temperature. IMD does not provide the data on PV leaf cell temperature; hence, it has to be measured or estimated using 
mathematical models. In literature, the nominal operating cell temperature (NOCT) model shown in Equation (2) is most widely used [8].

$$
T_{P V \text { Leaf }}=T_{\text {air }}+\left[\left(\frac{\mathrm{NOCT}-20}{800}\right) \times G_{P O-P V \text { Leaf }}\right]
$$

In the NOCT model, the cell temperature of the open-circuited cells in a PV module is estimated by assuming the plane of irradiance, reference temperature, and wind speed as $800 \mathrm{~W} / \mathrm{m}^{2}, 20^{\circ} \mathrm{C}$, and $1 \mathrm{~m} / \mathrm{s}$. However, in the case of the SPVT, each PV leaf is at different tilt angles, different orientations, and at different heights. The experienced weather parameters are varied, which ultimately affects the rise in cell temperatures. In addition, in this study, we used different solar cell technologies; hence, the NOCT model's use may not be reliable to estimate cell temperatures.

Using Equations (3)-(5), the effect of cell temperature, the PV leaf mounting height on the experienced wind speed, and solar cell technology for the PV leaf can be considered while evaluating the energy outputs. The rise in module temperature is shown in Equation $(3)[8,35]$ :

$$
T_{P V \text { Leaf }}=T_{a m b}+\left[\frac{G_{P O-P V \text { Leaf }}}{U_{1}+\left(U_{2} \times W_{S}\right)}\right]
$$

where $T_{a m b}$ is the ambient temperature at the installed site in ${ }^{\circ} \mathrm{C} ; U_{1}$ and $U_{2}$ are the Faiman coefficients for the chosen solar cell technology as the PV leaf shown in Table 4; and $W_{s}$ is the wind speed experienced by the PV leaf in $\mathrm{m} / \mathrm{s}$.

Table 4. Faiman coefficients for solar cell technologies used as a photovoltaic leaf [35].

\begin{tabular}{lcc}
\hline \multirow{2}{*}{ Solar Cell Technology } & \multicolumn{2}{c}{ Faiman Coefficients for Different Solar Cell Technologies } \\
\cline { 2 - 3 } & $U_{1}$ & $U_{2}$ \\
\hline Crystalline silicon (c-Si) & 30.02 & 6.28 \\
Copper indium gallium selenide (CIGS) & 22.19 & 4.09 \\
Cadmium telluride (CdTe) & 23.37 & 5.44 \\
\hline
\end{tabular}

In the SPVT, each PV leaf is mounted at different heights, and the wind speeds as per the mounted height are evaluated using Equations (4) and (5) while considering the base level wind speeds [36]:

$$
\begin{gathered}
W_{s}=W_{s_{-} r e f} \times\left(\frac{Z}{Z_{r e f}}\right)^{n} \\
n=\frac{0.37-0.0881 \times \ln \left(W_{s_{-} r e f}\right)}{1-0.0881 \times \ln \left(\frac{Z_{r e f}}{10}\right)}
\end{gathered}
$$

where $W_{s_{-} \text {ref }}$ is the reference wind speed at the base or reference height in $\mathrm{m} / \mathrm{s}$; is the reference height in $\mathrm{m} ; \mathrm{Z}$ is the height at which wind speed is estimated, i.e., the mounting height of the PV leaf in $\mathrm{m}$; and $n$ is the coefficient that can be calculated using Equation (5).

Using the above-discussed methodology as per Equations (1)-(5), a PV leaf's energy outputs are estimated. The proposed SPVT is a combination of 9 PV leaves; hence, each PV leaf's cumulative energy outputs will be the overall energy output of the SPVT, as seen in Equation (6):

$$
E_{S P V T}=E_{P V \text { Leaf-ul_OS }}+\sum_{i=N E, S E, S W, N W} E_{P V \text { Leaf }-m l_{-} i}+\sum_{j=N, E, S, W} E_{P V \text { Leaf-bl_j }}
$$

where $E_{S P V T}$ is the energy output of the SPVT in $\mathrm{kWh} /$ day; $E_{P V}$ Leaf-ul_os is the energy output of the open-sky mounted PV leaf in $\mathrm{kWh} /$ day; and $E_{P V}$ Leaf-ml_i is the energy output of the PV leaves mounted in different directions in the middle layer of the SPVT in $\mathrm{kWh} / \mathrm{day}$; 
The annual energy outputs of the proposed 3-L SPVT are calculated by summing up the produced energy daily using Equation (7):

$$
A E_{S P V T}=\sum_{d=1}^{365} E_{S P V T \_d}
$$

where $A E_{S P V T}$ is the annual energy outputs of the SPVT in $\mathrm{kWh} ; E_{S P V T \_}$is the daily energy outputs from the SPVT in kWh; and $d$ is the day number, i.e., 1, 2, 3, . , 365.

In any PV applications, the overall performance is affected by the degradation, and this will be specific to the PV technology and operating conditions. Even in the case of the SPVT, each PV leaf would experience the issue of degradation; hence, it is essential to estimate the degradation-influenced energy outputs.

The degradation-influenced annual energy outputs are referred to as the effective annual energy output (i.e., $A E_{S P V T} E f f e$ ) for the SPVT and is evaluated using Equation (8) [37]:

$$
A E_{S P V T \_E f f e}=\left[\sum_{d=1}^{365}\left(E_{S P V T \_d}\right)\right]-\left(D R_{P V \text { Cell Tech_y }}\right)
$$

where $D R_{P V}$ Cell Tech $y$ is the annual energy degradation in $\mathrm{kWh}$. The PV degradation data should be climate and solar cell technology-specific. As per the approach described in Refs. [38,39], the data of solar cell degradation closely associated with a humid tropical climate were taken into consideration.

The lifetime energy output from the SPVT (i.e., $\left.L E_{S P V T} E f f e\right)$ is evaluated using Equation (9), which is the sum of the effective annual energy outputs for its lifetime (i.e., $l=25$ years).

$$
L E_{S P V T}=\sum_{l=1}^{25} A E_{S P V T \_E f f e_{-} l}
$$

\subsection{Modeling of the Solar Photovoltaics Tree Lifecycle Emissions}

The proposed 3-L SPVT system's sustainable performance is assessed based on the $\mathrm{CO}_{2}$ emissions released throughout its lifecycle. Here, a comparative assessment of the three different solar cell technologies (c-Si, CIGS, and CdTe) was considered, as our goal is to select the best performing solar cell technology for a PV leaf. For estimating the $\mathrm{CO}_{2}$ emissions, the lifecycle environmental assessments (LCEA) data were used. The goal of the LCEA is to cover the cradle-to-gate life of the c-Si, CIGS, and CdTe, which starts from the extraction of raw materials for producing the 3-L SPVT system and ends with the use phase where electricity production happens. The LCEA accounts for the possible materials inputs, energy consumption (that might be from the electricity grid or other thermal fuels), and effluents throughout the lifetime [40]. Here in this study, the cradle-to-gate lifecycle as seen in Figure 3 is chosen.

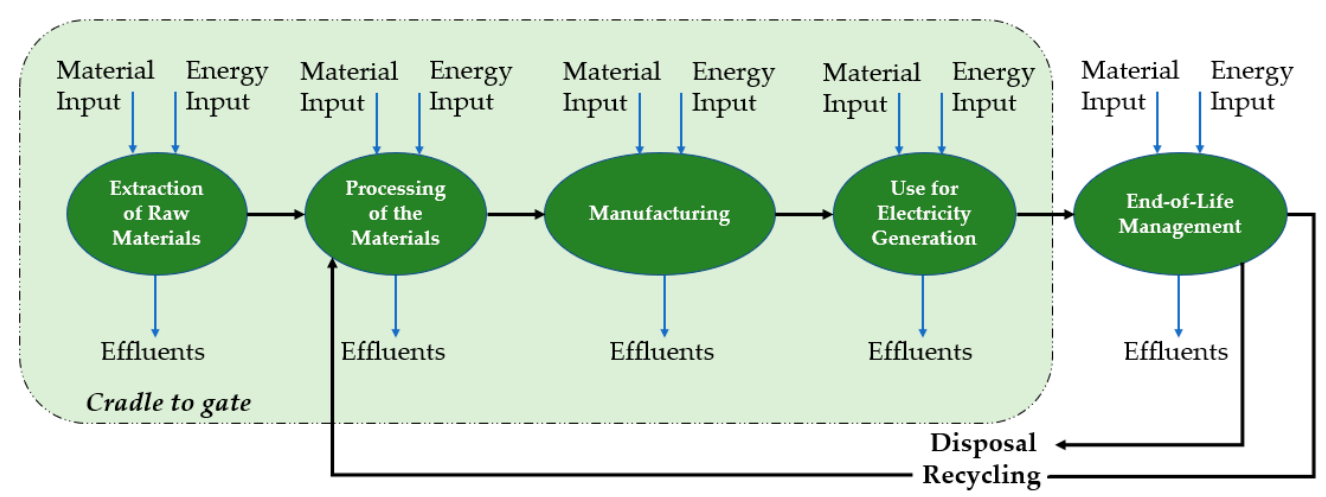

Figure 3. The lifecycle stages of the typical photovoltaic module and the system. 
The LCEA of various types of solar cells has been well studied in the literature. Peng and Yang (2013) conducted a detailed review highlighting the energy payback and greenhouse gas emission of different solar cells. The emission data related to the balance of the system used in various PV applications were also highlighted [41]. On the other side, the lifecycle inventories for the existing and emerging solar cells were given by the International Energy Agency-Photovoltaic Power Systems Programme Task 12 (IEA-PVPS-Task-12) [42].

\section{Performance Prioritization Approach Based on Energy and Sustainability Indicators}

A performance prioritization approach (PPA) based framework was proposed to select the best performing solar cell technology for a PV leaf used in the 3-L SPVT. The PPA framework is developed based on energy and sustainability performance indicators. In this approach, under the energy performance indicators, degradation-influenced lifetime energy outputs from the 3-L SPVT were evaluated by considering all the critical parameters. These critical parameters include solar irradiance, wind speed, ambient temperature, and module or cell temperature.

Likewise, under the sustainability performance indicators, lifecycle-based $\mathrm{CO}_{2}$ emissions from the 3-L SPVT were evaluated by considering the lifecycle inventory data. The estimated lifecycle $\mathrm{CO}_{2}$ emissions are based on the cradle-to-gate assessments for the c-Si, CIGS, and CdTe solar cell technologies. The lifecycle inventory data for the c-Si, CIGS, and CdTe solar cells include the materials inputs, energy inputs, and effluents from the raw material extraction stage to PV module manufacturing and the use phase. Once the lifetime energy outputs and lifecycle-based $\mathrm{CO}_{2}$ emissions were evaluated, the c-Si, CIGS, and CdTe solar cell technology PV-leaf based 3-L SPVTs were ranked. Using both the energy and sustainability indicators, a MATLAB program based on Algorithm A1 (see Appendix A) was developed to rank the best performing PV leaf in each layer and the best overall 3-L SPVT system. The proposed PPA framework is shown in Figure 4.

Weather

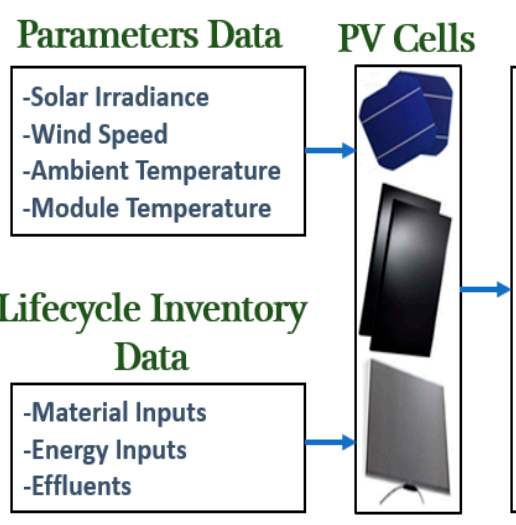

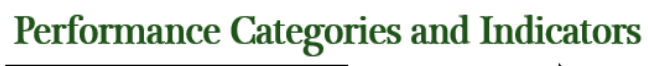

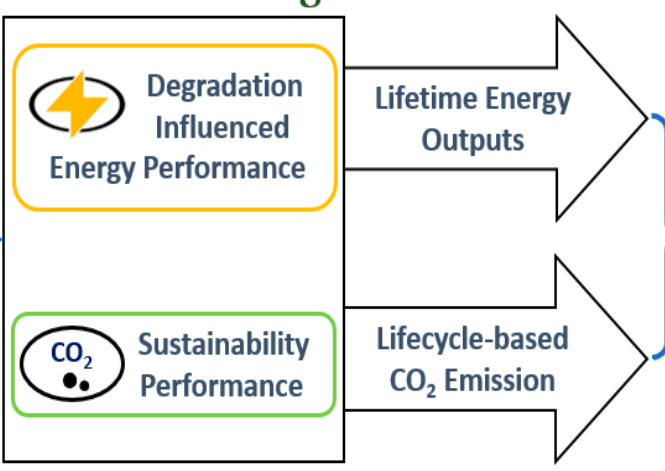

Best

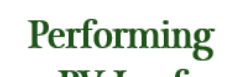

PV Leaf

(Maximum Energy Outputs and Minimum

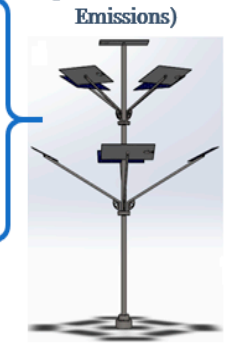

Figure 4. A framework based on a performance prioritization approach for selecting the photovoltaic leaf with maximum lifetime energy outputs and minimum lifetime emissions.

The ranking criteria are based on the maximum energy outputs and minimum emissions throughout the considered lifetime of the 3-L SPVT system. The criteria for ranking is represented mathematically using Equation (10):

$$
P P_{P V \text { Leaf }}=f\left(\max L E_{S P V T}, \min L E m_{S P V T}\right)
$$

where $P P_{P V}$ Leaf represents the prioritized photovoltaic leaf or the 3-L SPVT system based on the performance; $\max L E_{S P V T}$ is the maximum lifetime energy outputs in $\mathrm{kWh}$; and $\min L E m_{S P V T}$ is the minimum lifecycle $\mathrm{CO}_{2}$ emissions in $\mathrm{tCO}_{2}$-eq. 
The maxLE $E_{S P V T}$ is obtained based on solving the conditions presented in Algorithm A2 (see Appendix A) for selecting the maximum lifetime energy outputs. Similarly, minLEm $m_{S P V T}$ is obtained by solving the conditions as represented in Algorithm A3 (i.e., requirements for selecting the minimum lifecycle emission, see Appendix A). Based on the obtained values from Algorithms A2 and A3 (see Appendix A), the prioritization decision on choosing the best performing solar PV leaf technology was determined.

\section{Results and Discussion}

\subsection{Analysis of the Weather Parameters}

The weather parameters impact is the most difficult challenge with the PV systems. Unlike other PV applications, the SPVT performance is also influenced by the weather parameters such as solar irradiance, wind speeds, ambient, and cell temperatures. In the proposed 3-L SPVT, the PV leaves are arranged with varying installation configurations; hence, the structural design will inform us regarding the possible performance variations with the exposed weather parameters.

The monthly average of daily solar irradiance incident on each PV leaf in the three layers was analyzed for the 3-L SPVT and shown in Figure 5.

The range of the monthly average of daily solar irradiance incident on different PV leaves varied between 2.88 and $7.06 \mathrm{kWh} / \mathrm{m}^{2} /$ day. For the PV leaf oriented to the open sky, the monthly average of daily solar irradiance ranges between 4.83 and $6.78 \mathrm{kWh} / \mathrm{m}^{2} /$ day. In the middle layer, the observed ranges of variation of the monthly average of daily solar irradiance for the PV leaves mounted in $\mathrm{NE}, \mathrm{SE}$, SW, and NW are 3.31-6.02, 4.62-6.53, 4.67-6.93, and 3.58-6.68 $\mathrm{kWh} / \mathrm{m}^{2} /$ day, respectively. Similarly, in the bottom layer, the observed ranges of variation of the monthly average of daily solar irradiance for the PV leaves mounted in N, E, S, and W are 2.88-6.51, 4.37-6.15, 4.55-7.06, and $4.8-6.68 \mathrm{kWh} / \mathrm{m}^{2} /$ day, respectively.

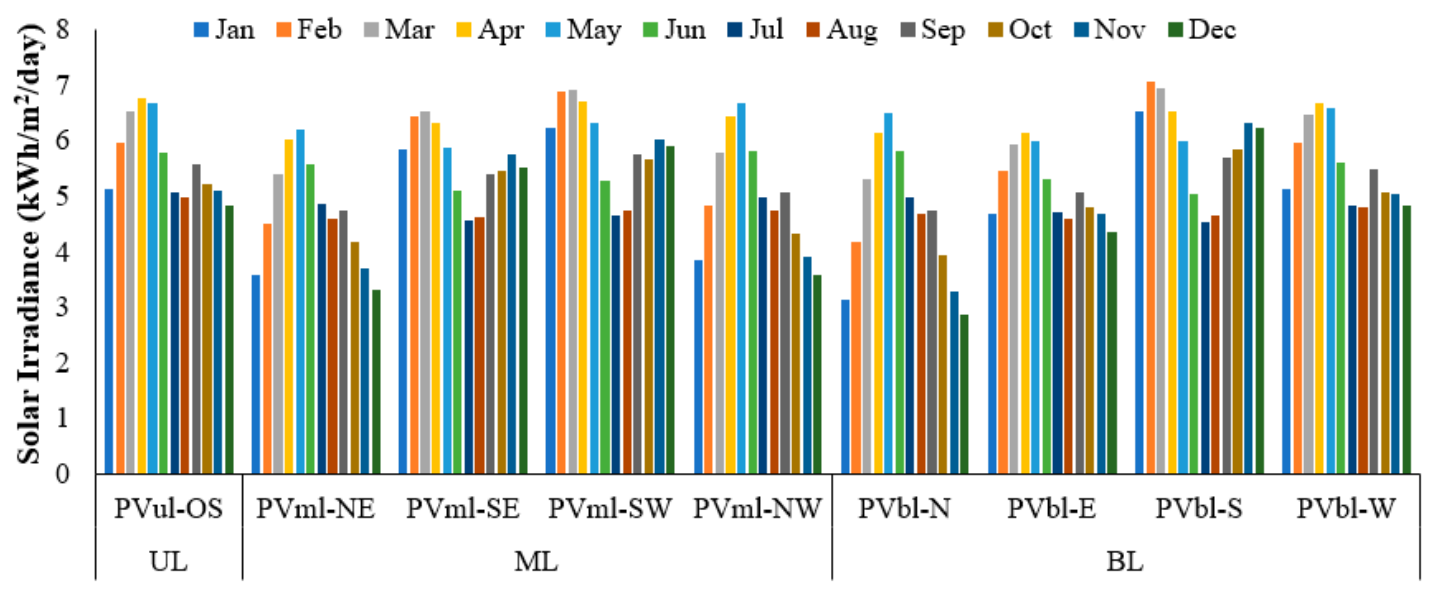

Photovoltaic Leaf in Different Layers of Solar Tree

Figure 5. Incident solar irradiance on the photovoltaic leaves in the proposed three-layered SPVT (3-L SPVT) system. Data source: Indian Meteorological Department (IMD).

The yearly average daily incident solar irradiance on the solar PV leaf mounted in the open sky configuration in the upper layer of the SPVT is $5.64 \mathrm{kWh} / \mathrm{m}^{2} /$ day. The solar PV leaves in the middle layer of the SPVT mounted in NE, SE, SW, and NW receives a yearly average daily incident solar irradiance of $4.72,5.62,5.93$, and $5 \mathrm{kWh} / \mathrm{m}^{2} /$ day, respectively. It is understood that the incident solar irradiance on the PV leaves in the middle layer is varied highly, and around $22.76 \%$ of a variation is observed when compared to other leaves in the same layer. Similarly, solar PV leaves in the bottom layer of the SPVT receives a yearly average daily incident solar irradiance of $4.63,5.14,5.95$, and $5.5 \mathrm{kWh} / \mathrm{m}^{2} /$ day for the N, E, S, and W orientations, respectively. The incident solar irradiance on the PV leaves in 
the bottom layer also varies highly, and around $24.95 \%$ of a variation is observed compared to other leaves in the same layer. Among all the three layers and the nine installation orientations, the solar PV leaf oriented in the south direction in the bottom layer experiences high incoming solar irradiance (i.e., $5.95 \mathrm{kWh} / \mathrm{m}^{2} /$ day). Similarly, the PV leaf oriented in the north direction in the bottom layer is identified to have the least incoming solar irradiance (i.e., $4.63 \mathrm{kWh} / \mathrm{m}^{2} /$ day).

The effect of wind speed and temperatures was considered while evaluating the energy outputs of each PV leaf. The sheer wind speeds at each solar PV leaf were estimated by considering the reference height's collected reference wind speeds. Figure 6 shows that wind speeds and temperatures are varied every month.

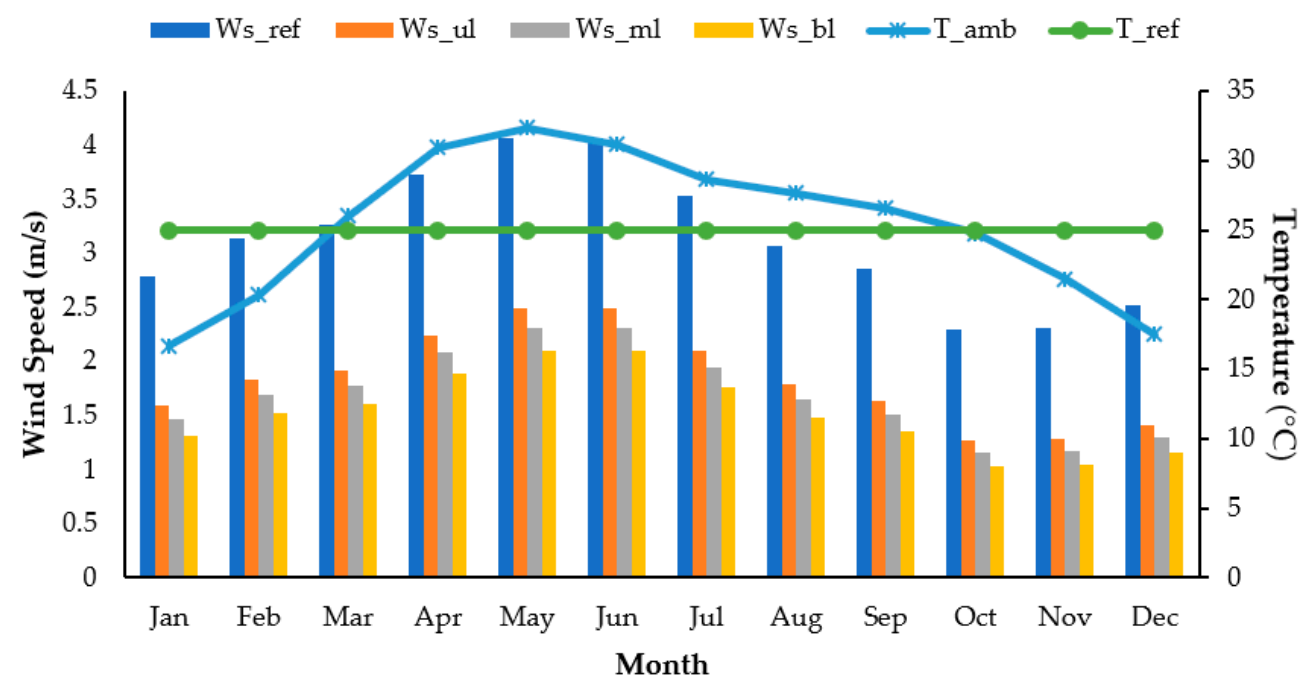

Figure 6. The observed wind speeds are the height variation of the three different layers of the proposed 3-L SPVT system and the ambient temperatures.

From Figure 6, it is understood that the sheer wind speeds at each PV leaf, which are based on its orientation and height at which they are mounted, are varied. The reference wind speed at $50 \mathrm{~m}$ is varied in the range of 2.29 to $4.07 \mathrm{~m} / \mathrm{s}$. The lowest observed reference wind speed is in October, and the highest is in May and June. The wind speeds at the upper layer (height $=9 \mathrm{~m}$ ), middle layer (height $=7 \mathrm{~m}$ ), and bottom layer (height $=5 \mathrm{~m}$ ) are estimated using the power law described in Equations (4) and (5). In the upper layer, the estimated wind speeds vary from 1.2 to $2.4 \mathrm{~m} / \mathrm{s}$ on an annual basis; in the middle layer, it ranges between 1.15 and $2.3 \mathrm{~m} / \mathrm{s}$, and in the bottom layer, it goes between 1.03 and $2.1 \mathrm{~m} / \mathrm{s}$. The considered reference temperature is $25^{\circ} \mathrm{C}$ as per the standard testing condition. Figure 6 shows the ambient temperatures, and they are observed to vary from 16.71 to $32.35^{\circ} \mathrm{C}$. The minimum temperature was observed in January, and the maximum was in May.

\subsection{Energy Analysis}

Using the solar PV leaf modeling approach presented in Section 3.1, each PV leaf's energy outputs were quantified based on their mounting conditions. In Tables 5-7, the monthly average of daily energy outputs of c-Si, CIGS, CdTe PV leaves of 3-L SPVT is presented. 
Table 5. Monthly average of daily energy outputs of c-Si photovoltaic leaves in the three different layers of the solar photovoltaic tree.

\begin{tabular}{|c|c|c|c|c|c|c|c|c|c|}
\hline \multirow{3}{*}{ Month } & \multicolumn{9}{|c|}{ Monthly Average of Daily Energy Outputs of C-Si Photovoltaic Leaf (kWh) } \\
\hline & \multirow{2}{*}{$\begin{array}{c}\text { Upper Layer } \\
\mathbf{P}_{u l-O S}\end{array}$} & \multicolumn{4}{|c|}{ Middle Layer } & \multicolumn{4}{|c|}{ Bottom Layer } \\
\hline & & $\mathbf{P}_{m l-N E}$ & $\mathbf{P}_{m l-S E}$ & $\mathbf{P}_{m l-S W}$ & $\mathbf{P}_{m l-N W}$ & $\mathbf{P}_{b l-N}$ & $\mathbf{P}_{b l-E}$ & $\mathbf{P}_{b l-S}$ & $\mathbf{P}_{b l-W}$ \\
\hline January & 0.53 & 0.37 & 0.60 & 0.64 & 0.40 & 0.32 & 0.48 & 0.67 & 0.53 \\
\hline February & 0.63 & 0.47 & 0.68 & 0.72 & 0.50 & 0.44 & 0.57 & 0.74 & 0.63 \\
\hline March & 0.71 & 0.58 & 0.70 & 0.75 & 0.62 & 0.57 & 0.64 & 0.75 & 0.69 \\
\hline April & 0.75 & 0.66 & 0.69 & 0.74 & 0.71 & 0.68 & 0.68 & 0.72 & 0.74 \\
\hline May & 0.74 & 0.69 & 0.65 & 0.70 & 0.74 & 0.72 & 0.66 & 0.67 & 0.73 \\
\hline June & 0.64 & 0.62 & 0.56 & 0.58 & 0.64 & 0.64 & 0.59 & 0.56 & 0.62 \\
\hline July & 0.55 & 0.53 & 0.50 & 0.51 & 0.54 & 0.54 & 0.51 & 0.49 & 0.53 \\
\hline August & 0.54 & 0.50 & 0.50 & 0.52 & 0.52 & 0.51 & 0.50 & 0.51 & 0.52 \\
\hline September & 0.60 & 0.51 & 0.59 & 0.62 & 0.55 & 0.51 & 0.55 & 0.61 & 0.59 \\
\hline October & 0.56 & 0.45 & 0.59 & 0.61 & 0.46 & 0.42 & 0.51 & 0.62 & 0.54 \\
\hline November & 0.54 & 0.39 & 0.61 & 0.64 & 0.41 & 0.34 & 0.49 & 0.67 & 0.53 \\
\hline December & 0.50 & 0.34 & 0.57 & 0.61 & 0.37 & 0.29 & 0.45 & 0.64 & 0.50 \\
\hline
\end{tabular}

From Table 5, it is noted that the c-Si PV-leaf based 3-L SPVT can generate electricity that varied approximately between 0.29 and $0.75 \mathrm{kWh}$. The c-SI PV leaf in the upper layer that is oriented to the open sky generates monthly average daily energy outputs that are ranged between 0.50 and $0.75 \mathrm{kWh}$. In the middle layer, the observed range of variation of the monthly average of daily energy outputs for the c-Si PV leaves mounted in NE, SE, SW, and NW are 0.34-0.69, 0.50-0.70, 0.51-0.75, and $0.37-0.74 \mathrm{kWh}$, respectively. Similarly, in the bottom layer, the observed range of variation of the monthly average of daily energy outputs for the c-Si PV leaves mounted in N, E, S, and W are $0.29-0.72,0.45-0.68,0.51-0.75$, and $0.50-0.74 \mathrm{kWh}$, respectively.

Table 6. Monthly average of daily energy outputs of CIGS photovoltaic leaves in the three different layers of the solar photovoltaic tree.

\begin{tabular}{|c|c|c|c|c|c|c|c|c|c|}
\hline \multirow{3}{*}{ Month } & \multicolumn{9}{|c|}{ Monthly Average of Daily Energy Outputs of CIGS Photovoltaic Leaf (kWh) } \\
\hline & \multirow{2}{*}{$\begin{array}{c}\text { Upper Layer } \\
\mathbf{P}_{u l-O S}\end{array}$} & \multicolumn{4}{|c|}{ Middle Layer } & \multicolumn{4}{|c|}{ Bottom Layer } \\
\hline & & $\mathbf{P}_{m l-N E}$ & $\mathbf{P}_{m l-S E}$ & $\mathbf{P}_{m l-S W}$ & $\mathbf{P}_{m l-N W}$ & $\mathbf{P}_{b l-N}$ & $\mathbf{P}_{b l-E}$ & $\mathbf{P}_{b l-S}$ & $\mathbf{P}_{b l-W}$ \\
\hline January & 0.43 & 0.30 & 0.49 & 0.52 & 0.32 & 0.26 & 0.39 & 0.55 & 0.43 \\
\hline February & 0.51 & 0.38 & 0.55 & 0.59 & 0.41 & 0.36 & 0.47 & 0.60 & 0.51 \\
\hline March & 0.57 & 0.47 & 0.57 & 0.61 & 0.51 & 0.47 & 0.52 & 0.61 & 0.57 \\
\hline April & 0.61 & 0.54 & 0.57 & 0.60 & 0.58 & 0.55 & 0.55 & 0.59 & 0.61 \\
\hline May & 0.60 & 0.56 & 0.53 & 0.57 & 0.60 & 0.59 & 0.54 & 0.54 & 0.60 \\
\hline June & 0.52 & 0.50 & 0.46 & 0.47 & 0.52 & 0.52 & 0.48 & 0.45 & 0.50 \\
\hline July & 0.45 & 0.43 & 0.41 & 0.41 & 0.44 & 0.44 & 0.42 & 0.40 & 0.43 \\
\hline August & 0.44 & 0.41 & 0.41 & 0.42 & 0.42 & 0.41 & 0.41 & 0.41 & 0.42 \\
\hline September & 0.49 & 0.42 & 0.48 & 0.51 & 0.45 & 0.42 & 0.44 & 0.50 & 0.48 \\
\hline October & 0.45 & 0.36 & 0.48 & 0.49 & 0.38 & 0.34 & 0.42 & 0.51 & 0.44 \\
\hline November & 0.44 & 0.32 & 0.50 & 0.52 & 0.33 & 0.28 & 0.40 & 0.54 & 0.43 \\
\hline December & 0.41 & 0.28 & 0.47 & 0.50 & 0.30 & 0.24 & 0.37 & 0.52 & 0.41 \\
\hline
\end{tabular}

From Table 6, it is understood that the monthly electricity productions from the CIGS PV-leaf based 3-L SPVT are varied between 0.24 and $0.61 \mathrm{kWh}$. The monthly average daily energy outputs of the CIGS PV leaf in the upper layer oriented to open sky are varied between 0.41 and $0.61 \mathrm{kWh}$. In the middle layer, the observed range of variation in the monthly average of daily energy outputs for the CIGS PV leaves mounted in NE, SE, SW, NW are 0.28-0.56, 0.41-0.57, 0.41-0.61, and 0.30-0.60 kWh, respectively. Similarly, in the bottom layer, the CIGS PV leaves mounted in N, E, S, and W orientations 
generate monthly average of daily energy outputs whose range is varied at $0.24-0.59,0.37-0.55$, $0.40-0.61$, and $0.41-0.0 .61 \mathrm{kWh}$, respectively.

Table 7. Monthly average of daily energy outputs of CdTe photovoltaic leaves in the three different layers of the solar photovoltaic tree.

\begin{tabular}{|c|c|c|c|c|c|c|c|c|c|}
\hline \multirow{3}{*}{ Month } & \multicolumn{9}{|c|}{ Monthly Average of Daily Energy Outputs of Cdte Photovoltaic Leaf (kWh) } \\
\hline & \multirow{2}{*}{$\begin{array}{c}\text { Upper Layer } \\
\mathbf{P}_{\text {ul-OS }}\end{array}$} & \multicolumn{4}{|c|}{ Middle Layer } & \multicolumn{4}{|c|}{ Bottom Layer } \\
\hline & & $\mathbf{P}_{m l-N E}$ & $\mathbf{P}_{m l-S E}$ & $\mathbf{P}_{m l-S W}$ & $\mathbf{P}_{m l-N W}$ & $\mathbf{P}_{b l-N}$ & $\mathbf{P}_{b l-E}$ & $\mathbf{P}_{b l-S}$ & $\mathbf{P}_{b l-W}$ \\
\hline January & 0.52 & 0.36 & 0.60 & 0.64 & 0.39 & 0.32 & 0.48 & 0.67 & 0.52 \\
\hline February & 0.62 & 0.47 & 0.67 & 0.71 & 0.50 & 0.43 & 0.56 & 0.73 & 0.62 \\
\hline March & 0.70 & 0.57 & 0.69 & 0.73 & 0.61 & 0.56 & 0.63 & 0.73 & 0.68 \\
\hline April & 0.73 & 0.65 & 0.68 & 0.72 & 0.69 & 0.66 & 0.66 & 0.70 & 0.72 \\
\hline May & 0.72 & 0.67 & 0.63 & 0.68 & 0.72 & 0.70 & 0.65 & 0.65 & 0.71 \\
\hline June & 0.62 & 0.60 & 0.55 & 0.57 & 0.62 & 0.62 & 0.57 & 0.54 & 0.60 \\
\hline July & 0.54 & 0.52 & 0.49 & 0.50 & 0.53 & 0.53 & 0.50 & 0.48 & 0.52 \\
\hline August & 0.53 & 0.49 & 0.49 & 0.52 & 0.51 & 0.50 & 0.49 & 0.50 & 0.51 \\
\hline September & 0.59 & 0.50 & 0.57 & 0.61 & 0.54 & 0.50 & 0.54 & 0.60 & 0.58 \\
\hline October & 0.55 & 0.44 & 0.57 & 0.60 & 0.46 & 0.41 & 0.52 & 0.61 & 0.53 \\
\hline November & 0.53 & 0.38 & 0.60 & 0.63 & 0.41 & 0.34 & 0.49 & 0.66 & 0.52 \\
\hline December & 0.49 & 0.34 & 0.57 & 0.61 & 0.37 & 0.30 & 0.45 & 0.64 & 0.50 \\
\hline
\end{tabular}

Similar to the other two types of PV leaves, the energy outputs of CdTe are observed. From Table 7, it is noted that the CdTe PV-leaf based 3-L SPVT can generate electricity that varied approximately between 0.30 and $0.73 \mathrm{kWh}$. The CdTe PV leaf in the upper layer oriented to the open sky generates monthly average daily energy outputs whose range is between 0.49 and $0.73 \mathrm{kWh}$. In the middle layer, the observed range of variation of the monthly average of daily energy outputs for the CdTe PV leaves mounted in NE, SE, SW, and NW are 0.34-0.67, 0.49-0.69, 0.50-0.73, and 0.37-0.72 kWh, respectively. Similarly, in the bottom layer, the observed range of variation of the monthly average of daily energy outputs for the CdTe PV leaves mounted in N, E, S, and W are 0.30-0.70, 0.45-0.66, $0.48-0.73$, and $0.50-0.72 \mathrm{kWh}$, respectively.

In Figure 7, the correlation between the incident solar irradiance and the daily energy outputs is shown for the three solar cell technology based 3-L SPVTs. Pearson's correlation coefficient $\left(R^{2}\right)$ is used to show the relationship between the solar irradiance and the daily energy outputs. Pearson's correlation coefficient measures both the linear relationship's strength and direction between two considered variables. It varies between -1 and +1 . A high absolute value means that the relationship is very strong. If the value ranges between 0 and $+1 /-1$, a relationship exists, but some points are out of the line. Furthermore, the sign of the correlation coefficient indicates the direction of the relationship. If the coefficient is positive, when a variable increase, the other variable also increases, getting an upward slope line, unlike the case where if the coefficient is negative, the other variable decreases when the variable increases, getting a downward slope line. Looking at Figure 7a-c, we can see that the $R^{2}$ values are 0.98 for all three technologies. This means that a strong (i.e., $R^{2}$ value around 1 ) and a positive correlation exists between the solar irradiance and energy outputs. Therefore, when the solar irradiance increases, the energy output of the 3-L SPVTs with the three solar cell technologies increases in a linear manner, and such a linear relationship's strength is the same for three types of PV leaves. The governing equations showing the relation between solar irradiance and energy outputs for the three types of PV leaves are different. This is due to the variation in the modeling parameters, including the temperature coefficient, efficiency, and Faiman coefficient. 


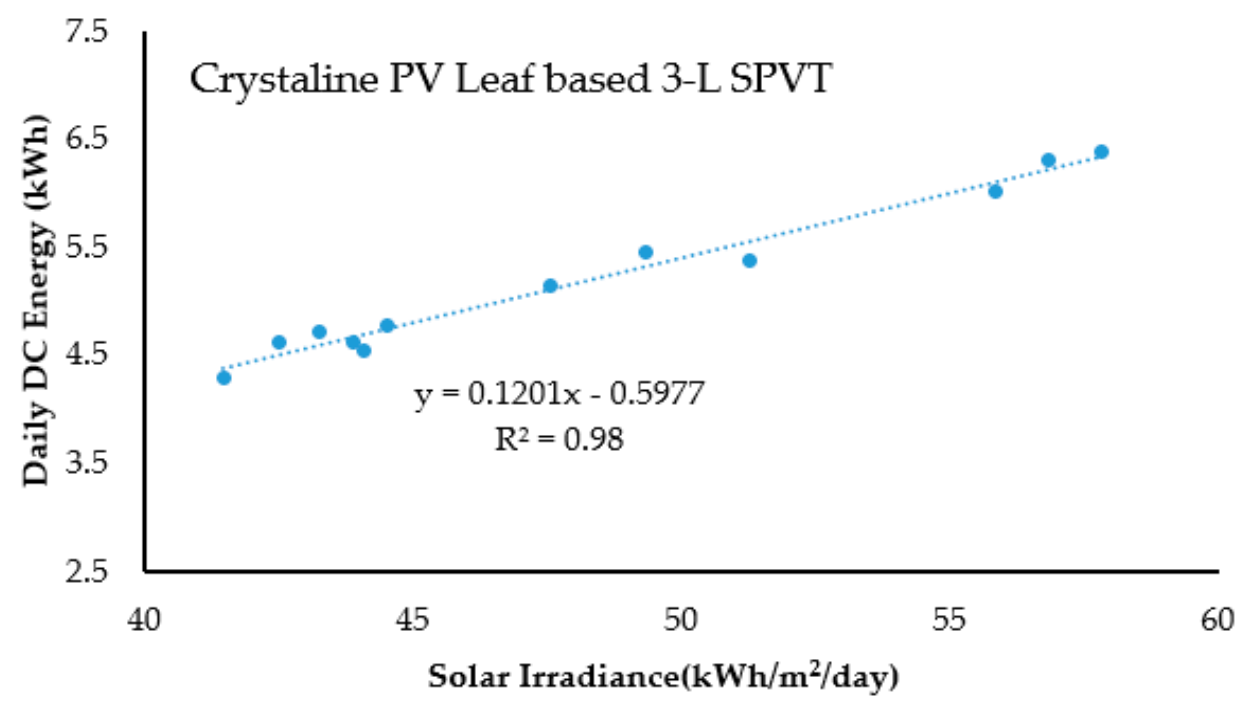

(a)

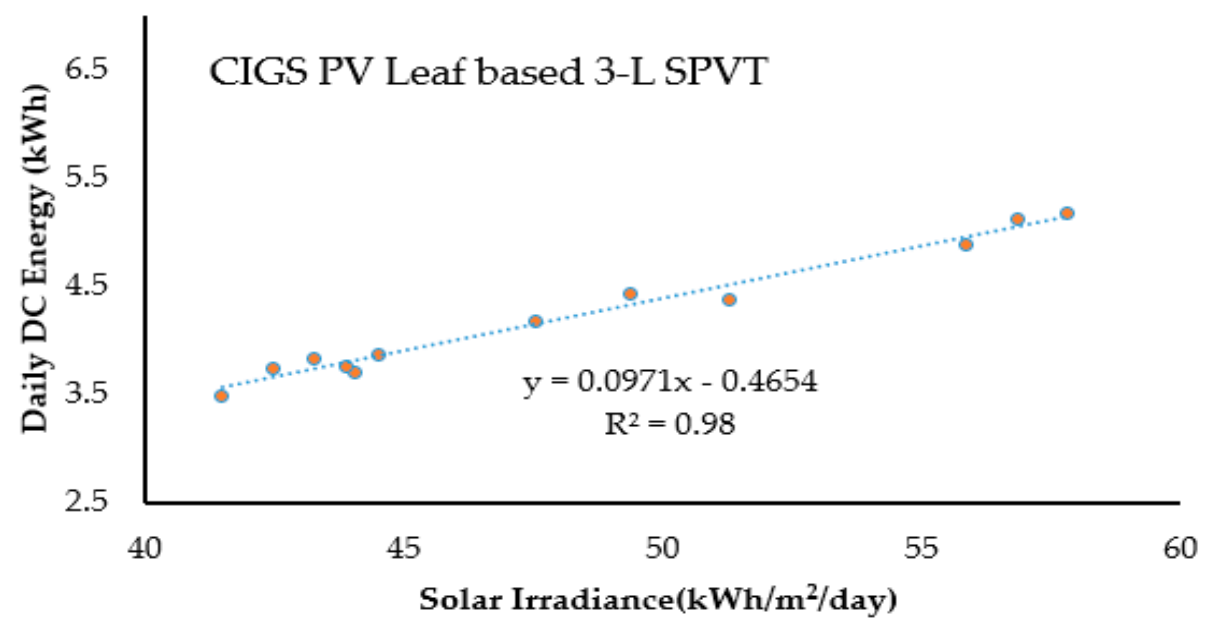

(b)

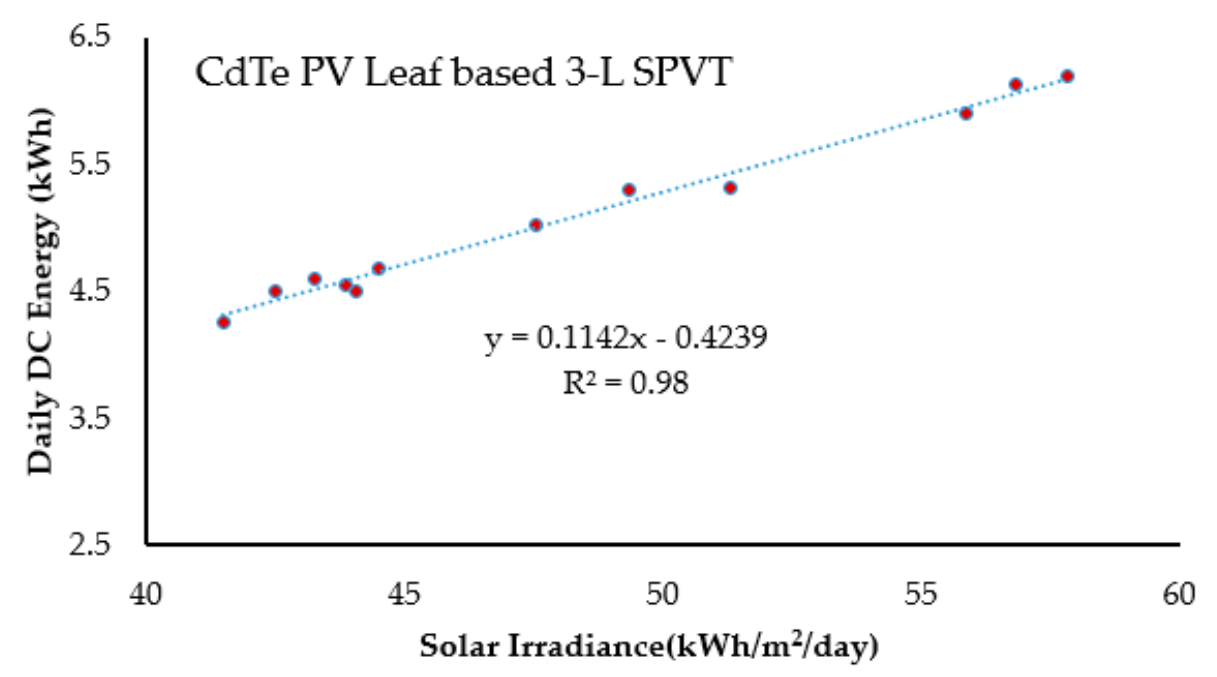

(c)

Figure 7. Relationship between the energy outputs and the incident solar irradiance (a). c-Si PV-leaf based 3-L SPVT; (b) CIGS PV-leaf based 3-L SPVT; (c) CdTe PV-leaf based 3-L SPVT. 
The monthly energy outputs for each PV leaf are evaluated using the daily generated energy outputs as per the investigated solar cell technologies (c-Si, CIGS, and CdTe) are evaluated, as seen in Figure 8. From Figure 8, it is understood that the three solar technologies demonstrated deviation in terms of energy generation for the same weather inputs and by using the same SPVT structure. Upon investigating the c-Si solar cell technology based 3-L SPVT, it is understood that the c-Si PV leaf oriented to open sky in the upper layer generates a monthly sum of energy outputs that vary between 15.50 and $22.96 \mathrm{kWh}$. In the middle layer, the observed range of variation of the monthly sum of energy outputs for the c-Si PV leaves mounted in NE, SE, SW, and NW are 10.62-21.34 kWh, 15.50-21.83, 15.80-23.17, and 11.49-22.99 kWh, respectively. Similarly, in the bottom layer, the observed range of variation of the monthly sum of energy outputs for the c-Si PV leaves mounted in N, E, S, and W are between 9.24-22.41, 14.03-20.62, 15.39-23.30, and 15.54-22.72 kWh, respectively.

Similarly, the CIGS-based 3-L SPVT reveals that the PV leaf oriented to the open sky in the upper layer generates a monthly sum of energy outputs that vary between 12.61 to $18.62 \mathrm{kWh}$. In the middle layer, the observed range of variation of the monthly sum of energy outputs for the CIGS PV leaves mounted in NE, SE, SW, NW are 8.64-17.31, 12.58-17.73, 12.82-18.82, and 9.34-18.65 kWh, respectively. Similarly, in the bottom layer, the observed range of variation of the monthly sum of energy outputs for the CIGS PV leaves mounted in N, E, S, and W are 7.52-18.17, 11.41-16.72, 12.49-18.84, and 12.64-18.43 kWh, respectively. Likewise, the analysis of the CdTe-based 3-L SPVT reveals that the PV leaf oriented to open sky in the upper layer generates a monthly sum of energy outputs that vary between 15.34 and $22.29 \mathrm{kWh}$. In the middle layer, the observed range of variation of the monthly sum of energy outputs for the CdTe PV leaves mounted in NE, SE, SW, and NW is 10. 51-20.72, 15.11-21.36, 15.41-22.67, and 11.37-22.32 kWh, respectively. Similarly, in the bottom layer, the observed range of variation of the monthly sum of energy outputs for the CdTe PV leaves mounted in N, E, S, and W are 9.14-21.75, 13.88-20.01, 15.01-22.71, and 15.37-22.05 kWh, respectively.

Considering that the three technologies have different efficiencies and temperature coefficients, in order to perform a meaningful comparison, the energy outputs were normalized to the corresponding value of the crystalline PV leaf as plotted in Figure 9. It can be seen that the crystalline PV leaf and the CdTe PV leaf show quite a similar energy performance with differences up to $3 \%$ during spring. The CIGS PV leaf underperforms with a difference in the energy output of $19 \%$ with respect to the c-Si PV leaf.

Based on the monthly sum of energy produced by each PV leaf, the annual energy outputs are evaluated, and they are discussed in Sections 5.2.1 and 5.2.2, while considering the effect of PV leaf mounting aspects and the possible degradation rate for each solar cell technology.

\subsubsection{Effect of Orientation, Layered Structure, and Solar Cell Technology Annual Energy Outputs}

This section discusses the effect of orientation, the layered structure, and the solar cell technology on the 3-L SPVT system's annual energy outputs. Figure 10 shows the yearly energy outputs of each PV leaf. From Figure 10, it is understood that the effect of orientation on the energy outputs is noticeable, and the same was thoroughly analyzed in Section 5.2, as the daily variations were also considered. Here, 9 PV leaves installed in different orientations are analyzed. Among these 9, the solar PV leaves oriented in the southwest (i.e., in the middle layer) and south (i.e., in the bottom layer) directions produced the maximum energies annually, and the minimum was by the PV leaf mounted in the north direction for the three different solar cell technologies.

The observed difference between the maximum energy-producing PV leaf to minimum energy-producing PV leaf is $23.88 \%, 23.98 \%$, and $24.05 \%$ for c-Si, CIGS, and CdTe solar cell technology based SPVTs, respectively. In addition, we observed that the difference in energy production between the middle and bottom layers is quite negligible, which is less than $0.025 \%$. 


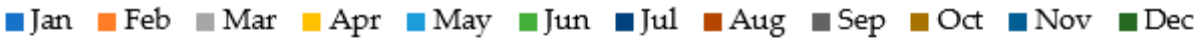

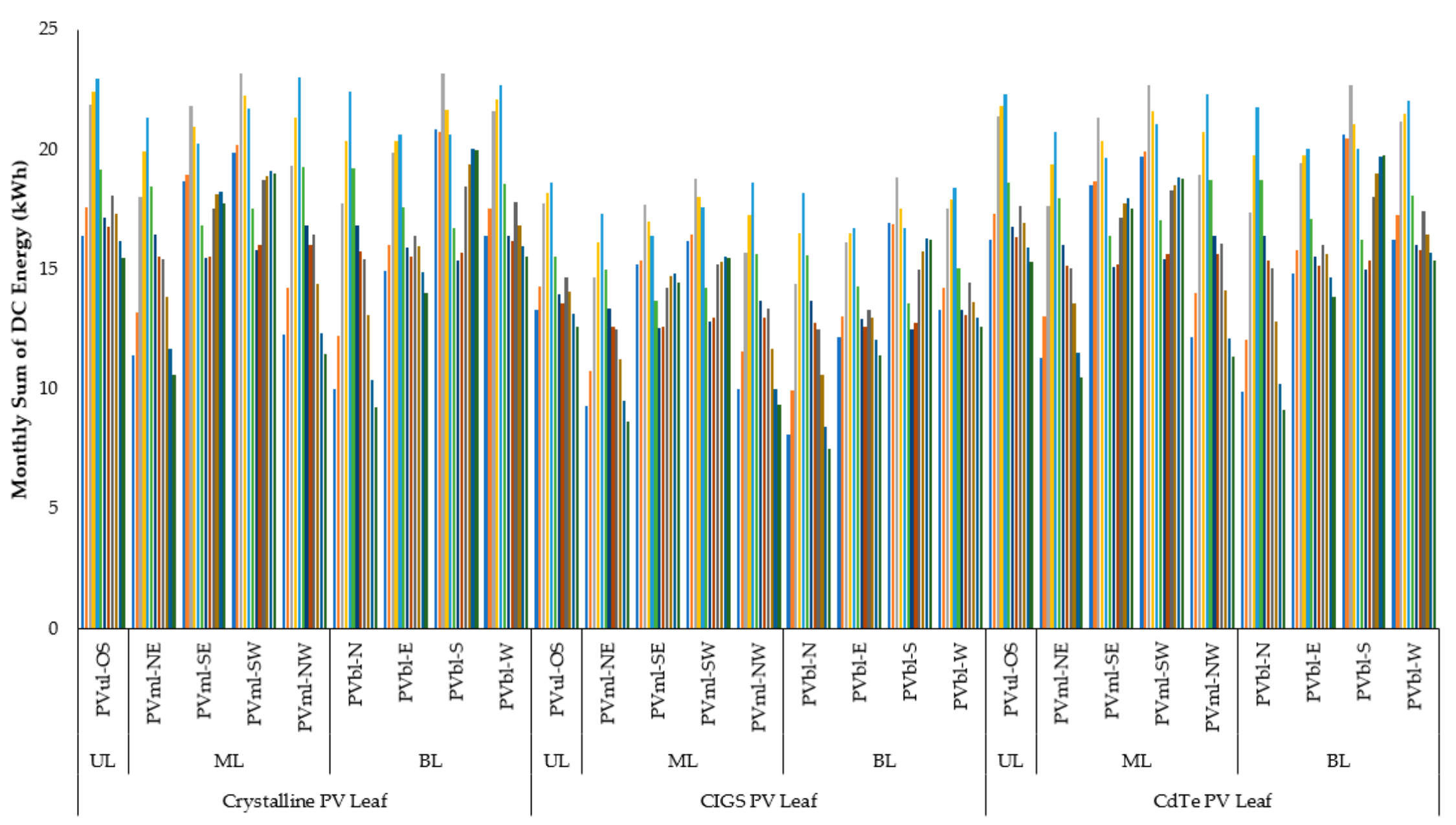

Figure 8. Comparison of monthly energy outputs of a solar photovoltaic tree in three different layers for the three different c-Si, CIGS, and CdTe solar cell technologies. 


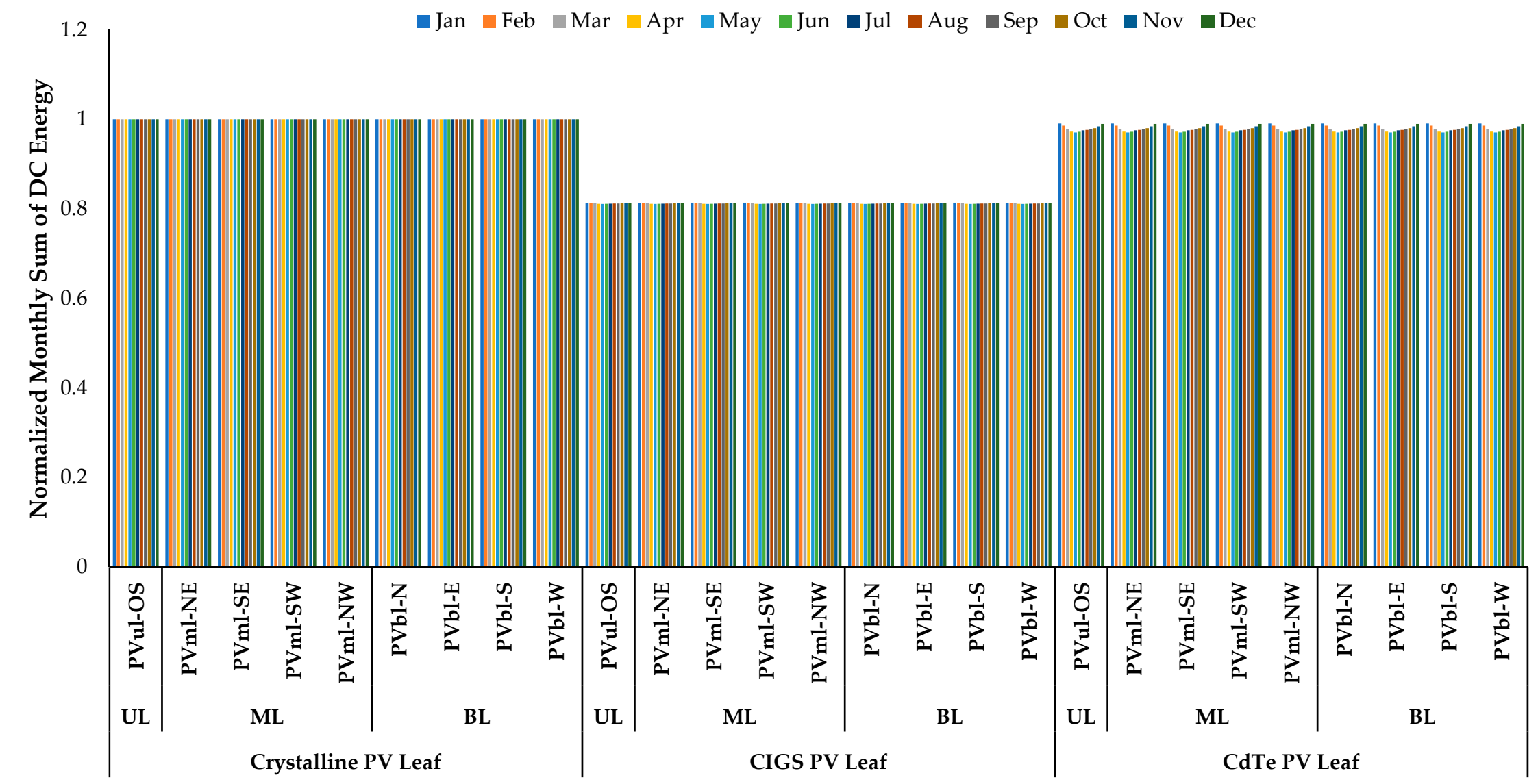

Figure 9. Comparison of normalized monthly energy outputs of a solar photovoltaic tree in three different layers for the three different c-Si, CIGS, and CdTe solar cell technologies. 


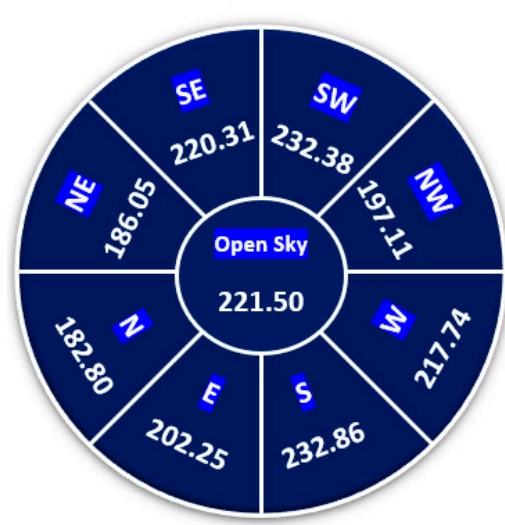

(a)

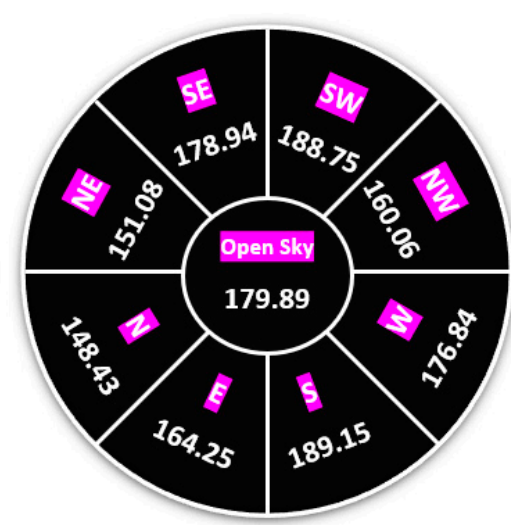

(b)

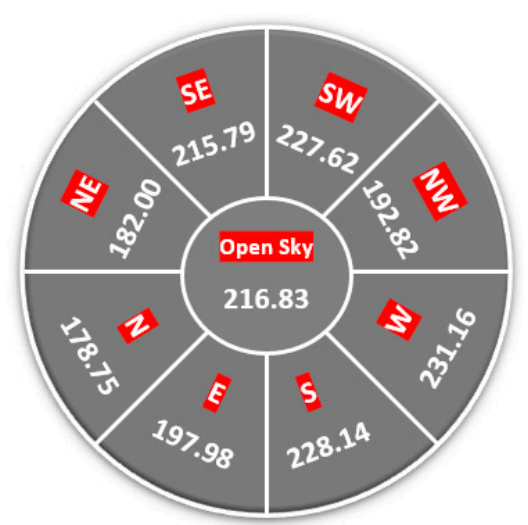

(c)

Figure 10. Comparing the solar PV leaves' annual energy outputs based on their installation orientation: (a) c-Si solar cell technology; (b) CIGS solar cell technology; (c) CdTe solar cell technology.

Upon comparing the solar cell technologies, it was observed that the c-Si technology based PV leaves perform well, followed by CdTe and CIGS. Regarding the annual energy outputs, the SPVT with c-Si, CIGS, and CdTe produces 1893.09, 1537.41, and $1853.14 \mathrm{kWh}$, respectively.

\subsubsection{Effect of Degradation Rates on the PV Leaf Annual Energy Outputs}

Degradation is one of the most affecting parameters on SPVT performance, and this is possible due to many factors (e.g., faults, breakdown, rust, and other risks) [43]. The degradation will vary differently for different weather conditions and operating patterns and will be more specific to the solar cell technology [44]. Here, the degradation data shown in Table 8 for the solar cell technology type were collected from the literature sources [45-47]. For degradation data collection, we only focused on the literature that compiled the data from various studies. One such study is the compendium of PV degradation rates (DRs) where Jordan et al. (2016) compiled 200 studies conducted across 40 different countries, in which approximately 11,000 DRs values resulted [45]. Similarly, a few other literature sources also reported DRs based on various sources, which can be seen in Refs. [46,47].

Table 8. The degradation rate of the chosen solar cell technologies as a photovoltaic leaf for the solar photovoltaic tree.

\begin{tabular}{lcc}
\hline \multicolumn{1}{c}{ Solar Cell Technology } & Degradation Rate (\%/Year) & Reference \\
\hline Crystalline silicon (c-Si) & 0.80 & \\
Copper indium gallium selenide (CIGS) & 1.86 & {$[45-47]$} \\
Cadmium telluride (CdTe) & 0.60 & \\
\hline
\end{tabular}

Using the data shown in Table 8, the degradation influenced energies are estimated for the 3-L SPVT system lifetime. The considered lifetime is 25 years. In Table 9 the lifetime energy outputs with and without considering the degradation for the c-Si, CIGS, and CdTe solar PV-leaf based 3-L SPVT systems are given.

Table 9. Lifetime energy outputs from the 3-L SPVT using the c-Si, CIGS, and CdTe solar PV leaves.

\begin{tabular}{lcc}
\hline \multicolumn{1}{c}{ Solar Cell Technology } & \multicolumn{2}{c}{ Lifetime Energy Outputs (kWh) } \\
\hline & Without Degradation & With Degradation \\
\hline Crystalline silicon (c-Si) & $47,325.98$ & $43,049.48$ \\
Copper indium gallium selenide (CIGS) & $38,435.34$ & $30,963.96$ \\
Cadmium telluride (CdTe) & $46,328.66$ & $43,141.49$ \\
\hline
\end{tabular}


In Figure 11, the degradation influenced lifetime energy outputs are illustrated for the c-Si, CIGS, and CdTe solar PV-leaf based 3-L SPVT system.

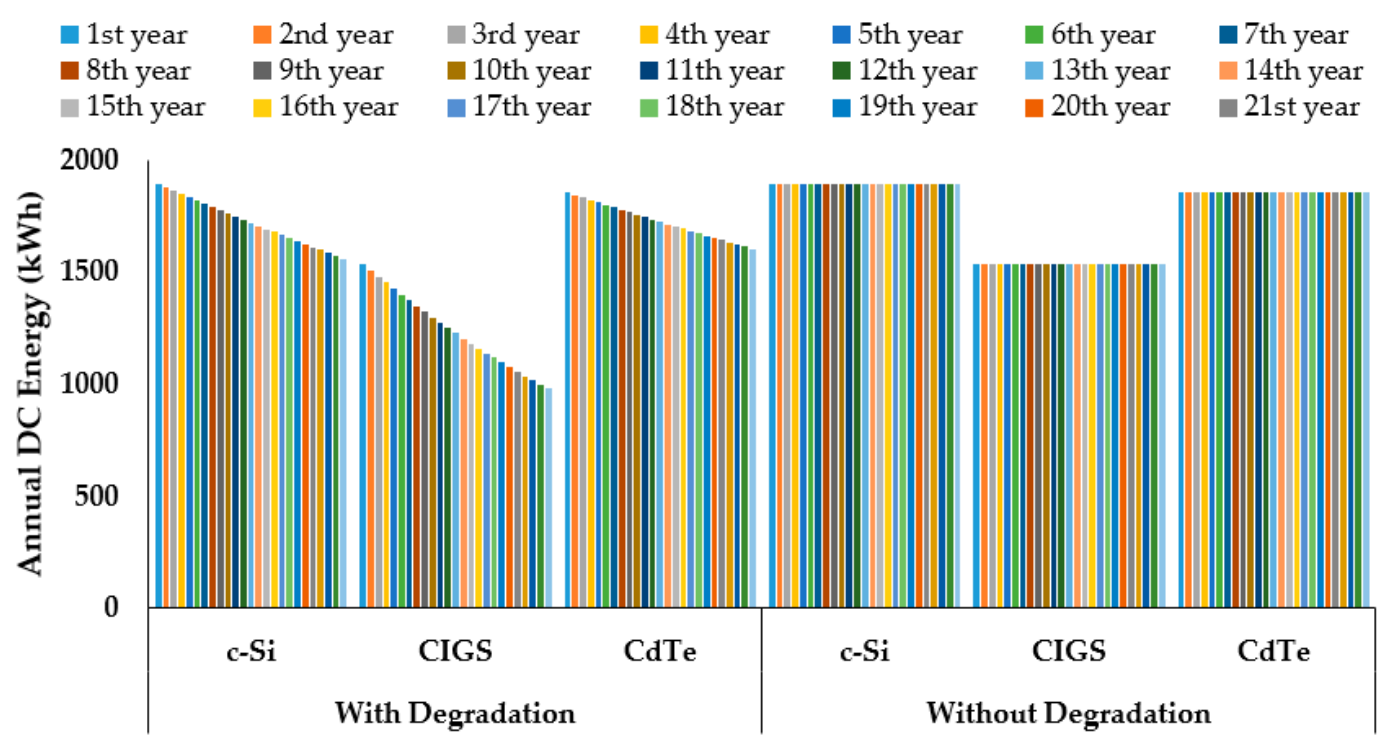

Figure 11. Comparison of degradation influenced energy outputs of a 3-L SPVT for the three different PV technologies.

From Figure 11, it is understood that the first year's observed energy outputs are 1893.09, 1537.41, and 1853.14 kWh for the c-Si, CIGS, and CdTe solar cell technology based SPVTs, respectively. Upon considering the degradation, the CdTe PV-leaf based 3-L SPVT was observed to perform well, followed by c-Si and CIGS, which is in line with the literature $[45,46]$. The overall observed difference in degradation-influenced energy outputs between $\mathrm{CdTe}$ and c-Si, and between CdTe and CIGS is $0.21 \%$ and $32.87 \%$, respectively. Similarly, the CIGS performs worst with $32.65 \%$ of the difference in energy outputs to its successor, i.e., c-Si. In considering the three solar cell technologies, it is understood that they have different degradation behavior throughout their lifetime, which is evident based on the literature $[38,39,45-47]$. To perform a meaningful comparison, the degradation-influenced energy outputs were normalized to the corresponding value of the c-Si PV-leaf based 3-L SPVT, as plotted in Figure 12.

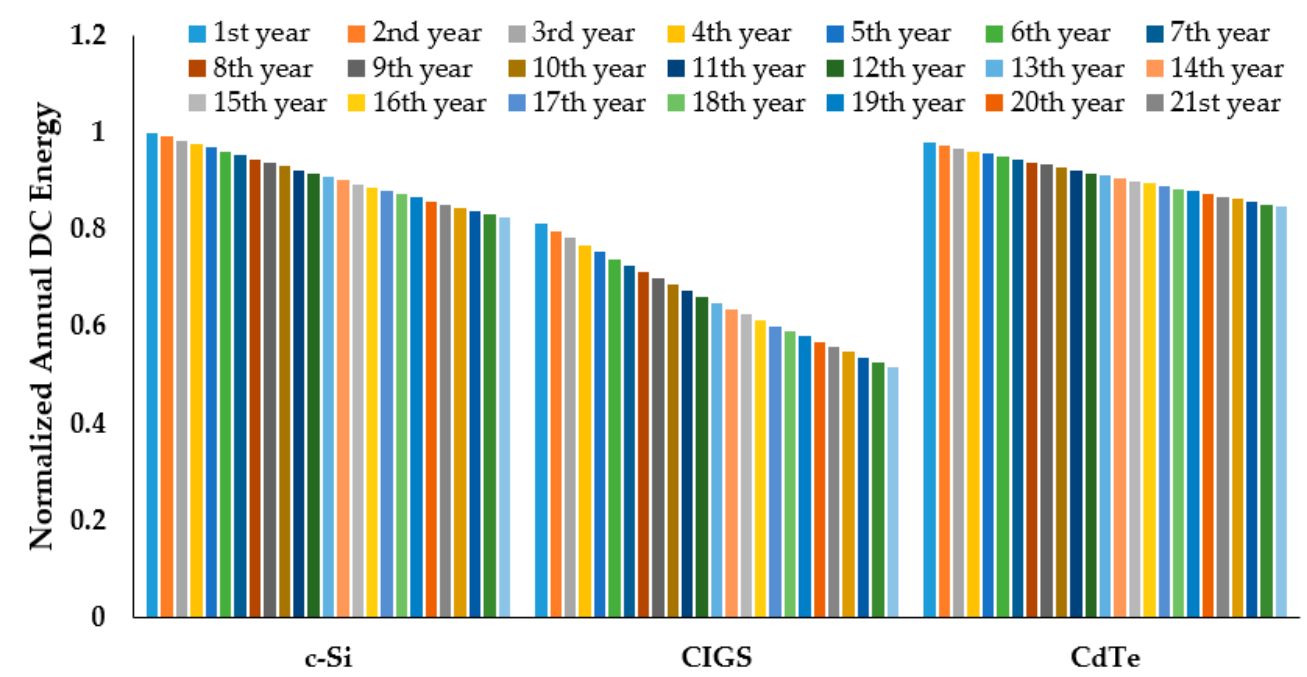

Figure 12. Comparison of normalized degradation influenced energy outputs of a 3-L SPVT for the three different PV technologies. 
It can be seen from Figure 12 that the normalized value dropped to 0.82, 0.52, and 0.84 from 1 in the case of the c-Si, CIGS, and CdTe PV-leaf based 3-L SPVTs, respectively. The CdTe PV-leaf based 3-L SPVT shows a favorable energy performance due to its lower degradation rates when compared to other two as per the current scenarios. The observed difference between the c-Si and CdTe is almost negligible.

\subsection{Emissions Analysis}

An emission analysis of the 3-L SPVT was carried out by considering the lifecycle-based $\mathrm{CO}_{2}$ emissions. In this study, emissions were evaluated based on the literature data [41-43]. We collected data on emissions per kWh of electricity production for the three solar technologies per the depicted lifecycle in Figure 3. The collected data from the literature are presented in Table 10.

Table 10. Lifecycle greenhouse gas emissions for the chosen solar cell technologies as a photovoltaic leaf for the solar photovoltaic tree.

\begin{tabular}{lcc}
\hline \multirow{2}{*}{ Solar Photovoltaic Cell Technology } & $\begin{array}{c}\text { Lifecycle-Based } \mathrm{CO}_{\mathbf{2}} \text { Emissions } \\
\text { (gCO } \mathbf{2}-\mathbf{e q} / \mathbf{k W h})\end{array}$ & \multirow{2}{*}{ Reference } \\
\cline { 2 - 2 } & Solar PV Leaf + Mounting Structure & \\
\hline Crystalline silicon (c-Si) & 23.64 \\
Copper indium gallium selenide (CIGS) & 24.47 & \\
Cadmium telluride (CdTe) & 16.94 & \\
\hline
\end{tabular}

The emissions from the 3-L SPVT system with three different solar PV leaf technologies were estimated by considering the case without degradation. The main reason for considering this is to quantify the actual emissions associated with the system. If degradation is accounted, the emissions associated with the lost energy due to degradation are simply ignored, but the total embodied emissions for the actual possible amount of energy will remain. Hence, the emissions are calculated for the 3-L SPVT without considering degradation. Emissions for c-Si PV leaves are observed as $1,118,786.22 \mathrm{gCO}_{2}$-eq, which are relatively high when compared to the other two solar cell technology based SPVT. The 3-L SPVT that uses CIGS PV leaves emits approximately 940,512.84 $\mathrm{gCO}_{2}$-eq, and the 3-L SPVT with CdTe-based PV leaves emits 784,807.43 $\mathrm{gCO}_{2}$-eq. In Figure 13, the released emissions in $\mathrm{tCO}_{2}$-eq for the produced electricity by the 3-L SPVTs using the three different solar cell technologies for the cases with degradation and without degradation are shown.

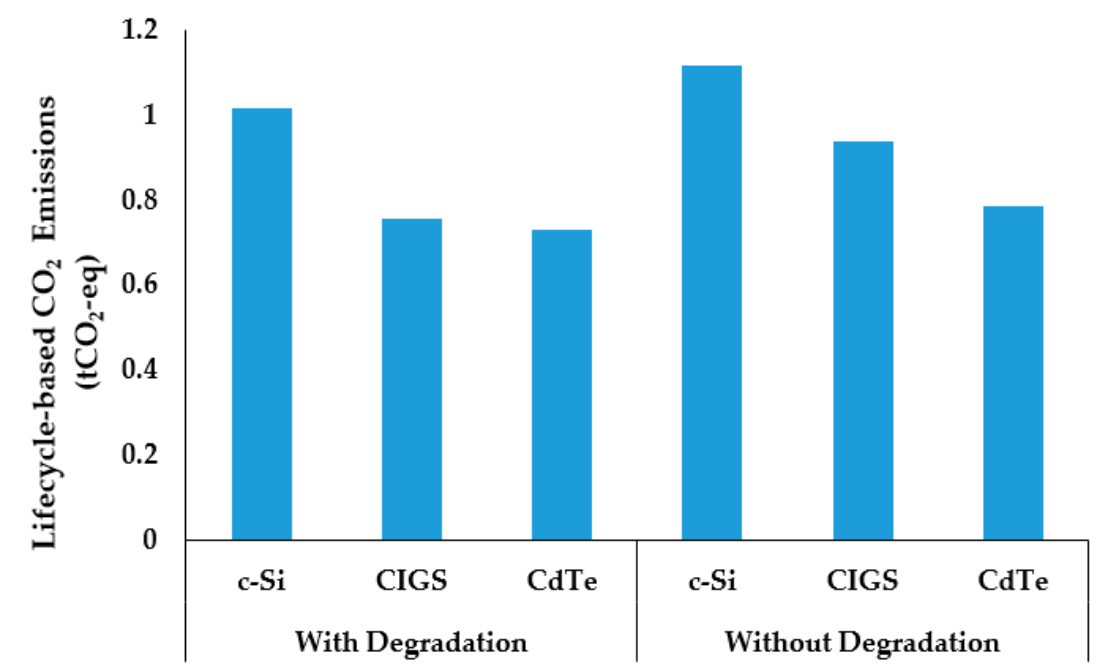

Figure 13. Lifecycle-based $\mathrm{CO}_{2}$ emissions per the produced electricity by the 3-L SPVT system with and without degradation. 


\subsection{Selection of Solar Cell Technologies for SPVTs Based on Energy and Sustainability Indicators}

In this section, the PV leaf selection based on the energy and sustainability indicators is discussed. The selection was based on the PPA under which the main criteria are maximum energy output and minimum emission (see Table 11). We observed that when degradation is considered, the conventional c-Si tends to perform more or less similarly to the CdTe. The c-Si PV-leaf based 3-L SPVT generated approximately $0.21 \%$ lower energy outputs than the CdTe PV-leaf based 3-L SPVT. The lifetime energy outputs of an SPVT with c-Si, CIGS, and CdTe are 43,049.48, 30,963.96, and 43,141.49 kWh, respectively. The emissions released from the 3-L SPVT with CdTe PV leaves are a lot lower when compared to the other two. Comparing specifically with the c-Si, the CdTe performs far better under the sustainability category. The energy and sustainability indicator-based ranking comparison between the three PV technologies confirms that the use of CdTe solar cells would be most beneficial for SPVT applications.

Table 11. Selection of solar cell technologies for SPVT leaves based on energy and sustainability indicator.

\begin{tabular}{|c|c|c|c|c|c|}
\hline \multirow{2}{*}{ 3-L SPVT } & \multirow{2}{*}{$\begin{array}{c}\text { Degradation-Influenced } \\
\text { Lifetime Energy } \\
\text { Outputs (kWh) }\end{array}$} & \multirow{2}{*}{$\begin{array}{l}\text { Lifecycle-Based } \\
\mathrm{CO}_{2} \text { Emissions } \\
\left(\mathrm{tCO}_{2}-\mathrm{eq}\right)\end{array}$} & \multicolumn{3}{|c|}{ Rank } \\
\hline & & & Energy & Sustainability & Overall \\
\hline c-Si PV leaf & $43,049.48$ & 1.12 & 2 & 3 & 2 \\
\hline CIGS PV leaf & $30,963.96$ & 0.94 & 3 & 2 & 3 \\
\hline CdTe PV leaf & $43,141.49$ & 0.79 & 1 & 1 & 1 \\
\hline
\end{tabular}

\section{Conclusions and Future Research Scope}

Overall, this study presents a brief analysis of the selection of solar cell technology for PV leaves used in the SPVT application. To understand the selection procedure, a multilayered case was proposed and investigated. In addition, an investigation of three different PV technologies was carried out, and the following conclusions were drawn:

- c-Si PV cells perform better when all the factors that affect performance are taken into account; however, this is found to be true for only a few years.

- When the DR is considered, the CdTe cells are observed to perform better for SPVT applications due to its lower degradation rates.

- It was observed that the PV cell degradation rate plays a crucial role in identifying the best performing PV technology for SPVTs.

- The CdTe solar PV leaves produced lower $\mathrm{CO}_{2}$ emissions when compared to the other two.

- In addition, the benefits associated with CdTe cells, such as a flexible structure, a ultrathin glass structure, and low-cost manufacturing, make them the best acceptable PV leaves for a SPVT design.

This study only focused on a direct current analysis; there is greater scope for conducting an alternating current analysis. Limiting this work to DC scope is to understand the sustainable selection process for PV leaves. On the other side, the considered case has 9 leaves, whose energy outputs vary with approximately a $23 \%$ difference; hence, feeding all the inputs to the power converter might have an impact. Therefore, we suggest the use of string inverters for each PV leaf depending upon its size. In most cases, the large-size SPVT systems might need such concepts.

Author Contributions: Conceptualization, N.M.K. and S.S.C.; data curation, N.M.K. and M.M.; formal analysis, N.M.K.; funding acquisition (Only APC), R.M.E. and N.D.; investigation, N.M.K. and S.S.C.; methodology, N.M.K. and S.S.C.; resources, S.S.C.; software, S.S.C.; supervision, S.S.C.; validation, N.M.K.; visualization, N.M.K.; writing—original draft, N.M.K.; writing—review and editing, N.M.K. and S.S.C. All authors have read and agreed to the published version of the manuscript.

Funding: The contribution of the School of Electrical and Computer Engineering, National Technical University of Athens was funded by the European Union's Horizon 2020 research and innovation programme under the Marie Skłodowska-Curie grant agreement No 799835

Conflicts of Interest: The authors declare no conflict of interest. 


\section{Appendix A}

The approach used for evaluating the energy and sustainability indicators is shown in Algorithm A1. Based on the obtained indicators, the solar cell technology that produces the maximum lifetime energy and minimum lifecycle emission is selected using the approach presented in Algorithm A2 and A3.
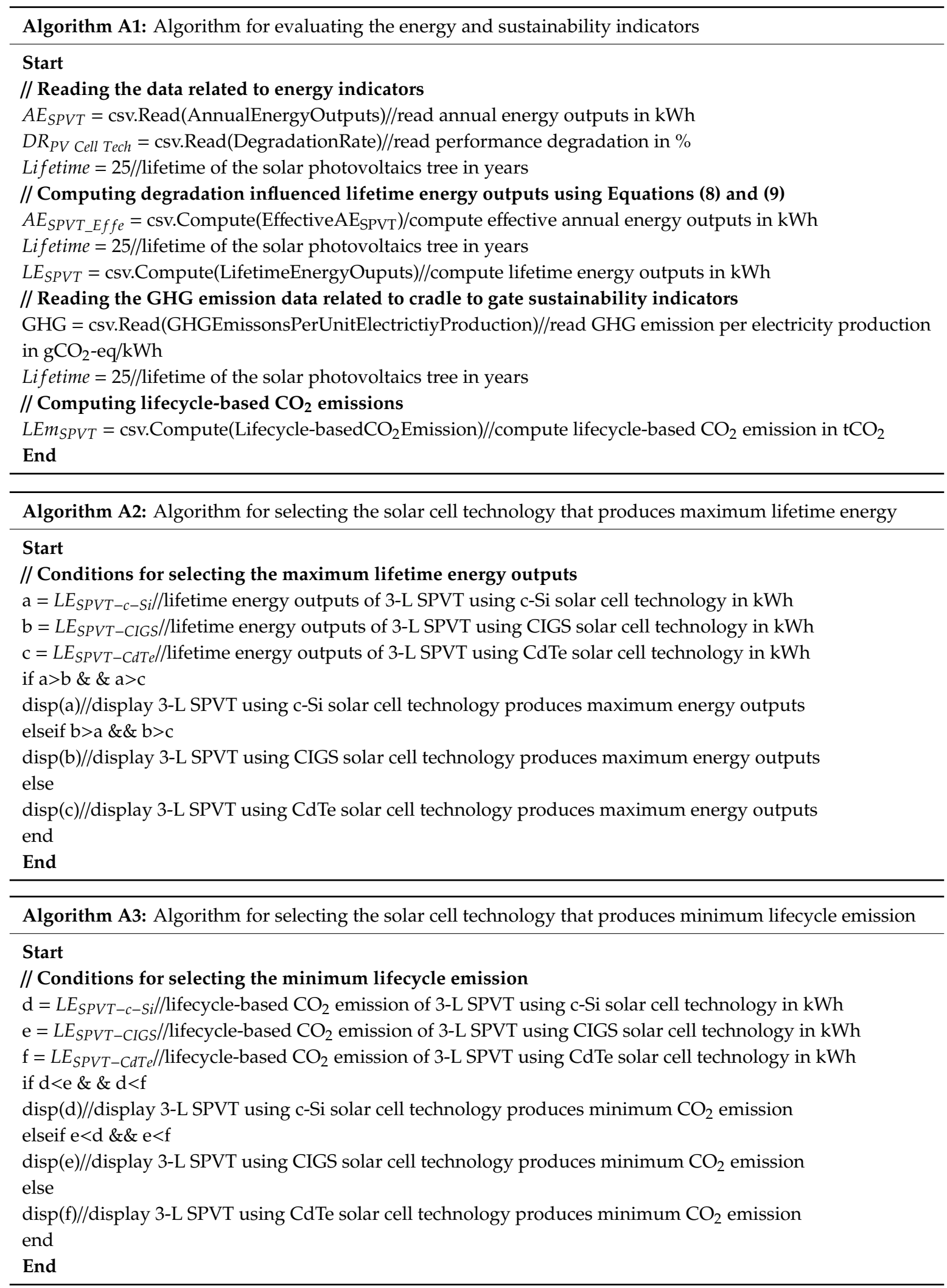


\section{References}

1. SDG Compass. SDG 7: Ensure Access to Affordable, Reliable, Sustainable and Modern Energy for All. Available online: https://sdgcompass.org/wp-content/uploads/2016/04/Goal_7.pdf (accessed on 2 September 2020).

2. Kumar, N.M.; Chopra, S.S.; Chand, A.A.; Elavarasan, R.M.; Shafiullah, G.M. Hybrid renewable energy microgrid for a residential community: A techno-economic and environmental perspective in the context of the SDG7. Sustainability 2020, 12, 3944. [CrossRef]

3. Aghaei, M.; Kumar, N.M.; Eskandari, A.; Ahmed, H.; de Oliveira, A.K.V.; Chopra, S.S. Solar PV systems design and monitoring. In Photovoltaic Solar Energy Conversion; Academic Press: Cambridge, MA, USA, 2020; pp. 117-145.

4. Kumar, N.M.; Reddy, P.R.K.; Praveen, K. Optimal energy performance and comparison of open rack and roof mount mono c-Si photovoltaic Systems. Energy Procedia 2017, 117, 136-144. [CrossRef]

5. Kumar, N.M.; Yadav, S.K.; Chopra, S.S.; Bajpai, U.; Gupta, R.P.; Padmanaban, S.; Blaabjerg, F. Operational performance of on-grid solar photovoltaic system integrated into pre-fabricated portable cabin buildings in warm and temperate climates. Energy Sustain. Dev. 2020, 57, 109-118. [CrossRef]

6. Attoye, D.E.; Tabet Aoul, K.A.; Hassan, A. A review on building integrated photovoltaic façade customization potentials. Sustainability 2017, 9, 2287. [CrossRef]

7. Reddy, P.; Gupta, M.V.N.; Nundy, S.; Karthick, A.; Ghosh, A. Status of BIPV and BAPV System for Less Energy-Hungry Building in India-A Review. Appl. Sci. 2020, 10, 2337. [CrossRef]

8. Kumar, N.M.; Sudhakar, K.; Samykano, M. Performance comparison of BAPV and BIPV systems with c-Si, CIS and CdTe photovoltaic technologies under tropical weather conditions. Case Stud. Therm. Eng. 2019, 13, 100374. [CrossRef]

9. Alghamdi, A.S.; Bahaj, A.S.; Wu, Y. Assessment of large scale photovoltaic power generation from carport canopies. Energies 2017, 10, 686. [CrossRef]

10. Araki, K.; Ota, Y.; Yamaguchi, M. Measurement and modeling of 3D solar irradiance for vehicle-integrated photovoltaic. Appl. Sci. 2020, 10, 872. [CrossRef]

11. Northmore, A.; Tighe, S. Innovative pavement design: Are solar roads feasible. In Conference $\mathcal{E}$ Exhibition of the Transportation Association of Canada (TAC); Transportation Association of Canada: Ottawa, ON, Canada, 2012.

12. Asanov, I.M.; Loktionov, E.Y. Possible benefits from PV modules integration in railroad linear structures. Renew. Energy Focus 2018, 25, 1-3. [CrossRef]

13. Amber, K.P.; Hussain, I.; Kousar, A.; Bashir, M.A.; Aslam, M.W.; Akbar, B. A self-cleaning device for pole mounted solar photovoltaic installations. Therm. Sci. 2019, 23 Pt A, 739-749.

14. Kumar, N.M.; Subramaniam, U.; Mathew, M.; Ajitha, A.; Almakhles, D.J. Exergy analysis of thin-film solar PV module in ground-mount, floating and submerged installation methods. Case Stud. Therm. Eng. 2020, 21, 100686. [CrossRef]

15. Ajitha, A.; Kumar, N.M.; Jiang, X.X.; Reddy, G.R.; Jayakumar, A.; Praveen, K.; Kumar, T.A. Underwater performance of thin-film photovoltaic module immersed in shallow and deep waters along with possible applications. Results Phys. 2019, 15, 102768. [CrossRef]

16. Kumar, N.M. Model to estimate the potential and performance of wavevoltaics. Results Phys. 2019, 12, 914-916. [CrossRef]

17. Gangwar, P.; Kumar, N.M.; Singh, A.K.; Jayakumar, A.; Mathew, M. Solar photovoltaic tree and its end-of-life management using thermal and chemical treatments for material recovery. Case Stud. Therm. Eng. 2019, 14, 100474. [CrossRef]

18. Gangwar, P.; Singh, R.; Tripathi, R.P.; Singh, A.K. Effective solar power harnessing using a few novel solar tree designs and their performance assessment. Energy Sources Part A Recovery Util. Environ. Eff. 2019, 41, 1828-1837. [CrossRef]

19. Hyder, F.; Baredar, P.; Sudhakar, K.; Mamat, R. Performance and land footprint analysis of a solar photovoltaic tree. J. Clean. Prod. 2018, 187, 432-448. [CrossRef]

20. Gholami, H.; Røstvik, H.N.; Kumar, N.M.; Chopra, S.S. Lifecycle cost analysis (LCCA) of tailor-made building integrated photovoltaics (BIPV) façade: Solsmaragden case study in Norway. Sol. Energy 2020, 211, 488-502. [CrossRef]

21. Kumar, N.M.; Kanchikere, J.; Mallikarjun, P. Floatovoltaics: Towards improved energy efficiency, land and water management. Int. J. Civ. Eng. Technol. 2018, 9, 1089-1096. 
22. García-Córdova, F.; Guerrero-González, A. Intelligent navigation for a solar powered unmanned underwater vehicle. Int. J. Adv. Robot. Syst. 2013, 10, 185. [CrossRef]

23. Manoj Kumar, N. Wavevoltaics: A new hybrid wave photon energy device. Curr. Sci. 2018, 115, 1251.

24. Hyder, F.; Sudhakar, K.; Mamat, R. Solar PV tree design: A REVIEW. Renew. Sustain. Energy Rev. 2018, 82, 1079-1096. [CrossRef]

25. Khan, H.; Gaur, P. Design of solar tree with photovoltaic panels using Fibonacci pattern. Adv. Res. Electr. Electron. Eng. 2015, 2, 67-71.

26. Maity, S.N. Development of solar power tree-an innovation that uses up very less land and yet generates much more energy from the sun rays by SPV method. J. Environ. Nanotechnol. 2013, 2, 59-69. [CrossRef]

27. Avdić, V.; Zečević, S.; Pervan, N.; Tasić, P.; Muminović, A.J. Different Design Solutions of Solar Trees in Urban Environment; University of Sarajevo: Sarajevo, Bosnia and Herzegovina, 2013; Volume 2, pp. 1-4.

28. Cao, W.; Li, Z.; Yang, Y.; Zheng, Y.; Yu, W.; Afzal, R.; Xue, J. "Solar tree": Exploring new form factors of organic solar cells. Renew. Energy 2014, 72, 134-139. [CrossRef]

29. Association ECOPOWER Solar Tree. Available online: http://www.association-ecopower.com/eco-marketing. html (accessed on 2 September 2020).

30. Manoj Kumar, N.; Ghosh, A.; Chopra, S.S. Power resilience enhancement of a residential electricity user using photovoltaics and a battery energy storage system under uncertainty conditions. Energies 2020, 13, 4193. [CrossRef]

31. Tata Solar Power Modules. Available online: https://www.tatapowersolar.com/ (accessed on 13 August 2020).

32. First Solar PV Module. Available online: http://www.firstsolar.com/Modules/Series-6 (accessed on 2 September 2020).

33. Nice Solar Energy. Available online: https://nice-solarenergy.com/en/cigs-modules.html (accessed on 2 September 2020).

34. India Meteorological Department (IMD), Ministry of Earth Sciences, Government of India (GoI). Available online: https://mausam.imd.gov.in/ (accessed on 10 August 2019).

35. Faiman, D. Assessing the outdoor operating temperature of photovoltaic modules. Prog. Photovolt. Res. Appl. 2008, 16, 307-315. [CrossRef]

36. Gökmen, N.H.; Hu, W.; Hou, P.; Chen, Z.; Sera, D.; Spataru, S. Investigation of wind speed cooling effect on PV panels in windy locations. Renew. Energy 2016, 90, 283-290. [CrossRef]

37. Kumar, N.M.; Prabaharan, N.; Jerin, R.A.; Jayakumar, A. Impact of performance degradation and capital subsidy on the revenue of rooftop PV system. Int. J. Renew. Energy Res. 2019, 9, 128-136.

38. Ascencio-Vásquez, J.; Kaaya, I.; Brecl, K.; Weiss, K.-A.; Topič, M. Global Climate Data Processing and Mapping of Degradation Mechanisms and Degradation Rates of PV Modules. Energies 2019, 12, 4749. [CrossRef]

39. Dubey, R.; Chattopadhyay, S.; Kuthanazhi, V.; Kottantharayil, A.; Singh Solanki, C.; Arora, B.M.; Narasimhan, K.L.; Vasi, J.; Bora, B.; Singh, Y.K.; et al. Comprehensive study of performance degradation of field-mounted photovoltaic modules in India. Energy Sci. Eng. 2017, 5, 51-64. [CrossRef]

40. Rajput, P.; Malvoni, M.; Manoj Kumar, N.; Sastry, O.S.; Jayakumar, A. Operational performance and degradation influenced life cycle environmental-economic metrics of mc-Si, a-Si and HIT photovoltaic Arrays in hot semi-arid climates. Sustainability 2020, 12, 1075. [CrossRef]

41. Peng, J.; Lu, L.; Yang, H. Review on life cycle assessment of energy payback and greenhouse gas emission of solar photovoltaic systems. Renew. Sustain. Energy Rev. 2013, 19, 255-274. [CrossRef]

42. Frischknecht, R.; Itten, R.; Sinha, P.; de Wild-Scholten, M.; Zhang, J.; Fthenakis, V.; Kim, H.C.; Raugei, M.; Stucki, M. Life Cycle Inventories and Life Cycle Assessments of Photovoltaic Systems (No. NREL/TP-6A20-73853); Report T12-04; National Renewable Energy Lab: Golden, CO, USA, 2015.

43. Rajput, P.; Malvoni, M.; Kumar, N.M.; Sastry, O.S.; Tiwari, G.N. Risk priority number for understanding the severity of photovoltaic failure modes and their impacts on performance degradation. Case Stud. Therm. Eng. 2019, 16, 100563. [CrossRef]

44. Jordan, D.C.; Deline, C.; Deceglie, M.G.; Nag, A.; Kimball, G.M.; Shinn, A.B.; John, J.J.; Alnuaimi, A.A.; Elnosh, A.B.A.; Luo, W.; et al. Reducing Interanalyst variability in photovoltaic degradation rate assessments. IEEE J. Photovolt. 2020, 10, 206-212. [CrossRef]

45. Jordan, D.C.; Kurtz, S.R.; VanSant, K.; Newmiller, J. Compendium of photovoltaic degradation rates. Prog. Photovolt. Res. Appl. 2016, 24, 978-989. [CrossRef] 
46. Phinikarides, A.; Kindyni, N.; Makrides, G.; Georghiou, G.E. Review of photovoltaic degradation rate methodologies. Renew. Sustain. Energy Rev. 2014, 40, 143-152. [CrossRef]

47. Jordan, D.C.; Kurtz, S.R. Photovoltaic degradation rates-An analytical review. Prog. Photovolt. Res. Appl. 2013, 21, 12-29. [CrossRef]

48. De Wild-Scholten, M.M. Energy payback time and carbon footprint of commercial photovoltaic systems. Sol. Energy Mater. Sol. Cells 2013, 119, 296-305. [CrossRef]

Publisher's Note: MDPI stays neutral with regard to jurisdictional claims in published maps and institutional affiliations.

(C) 2020 by the authors. Licensee MDPI, Basel, Switzerland. This article is an open access article distributed under the terms and conditions of the Creative Commons Attribution (CC BY) license (http://creativecommons.org/licenses/by/4.0/). 